Michat Choptiany

Wydział „Artes Liberales”

Uniwersytet Warszawski

\title{
Tradycja rękopiśmienna przepowiedni elekcyjnej Jerzego Joachima Retyka. Analiza przekazów i edycja*
}

Artykuł stanowi propozycję uporządkowania zagadnień związanych z dużym zróżnicowaniem przekazów rękopiśmiennych funkcjonujących razem pod nazwą „przepowiedni elekcyjnej”, przypisywanej Jerzemu Joachimowi Retykowi. Autor proponuje model pokazujący, w jaki sposób oryginalny, niezachowany do dnia dzisiejszego w postaci autografu tekst „przepowiedni”, po wprowadzeniu do obiegu rękopiśmiennego za sprawą korespondencji i wykonywanych licznie odpisów, ulegał procesom kontaminacji i interpolacji, przy jednoczesnym kształtowaniu się tradycji wernakularnych tego tekstu. Procesy te zostały zilustrowane w aneksach źródłowych zawierających edycje przekazów w języku łacińskim, polskim i niemieckim.

The paper aims to organise the issues concerning the great variety of manuscripts jointly described as the "election prophecy," supposedly made by Georg Joachim Rheticus. The author proposed to apply a model showing how the original text of the "prophecy," the autograph of which has not been preserved to this day, underwent contamination and interpolation after

* Dziękuję prof. Jarosławowi Włodarczykowi, dr Joannie Walewskiej, Aleksandrowi Sroczyńskiemu oraz anonimowym recenzentom za liczne wnikliwe uwagi, które pomogły mi w udoskonaleniu wcześniejszych wersji tekstu i skłoniły mnie do weryfikacji niektórych wstępnych sformułowań. Badania zostały sfinansowane ze środków Narodowego Centrum Nauki przyznanych w ramach finansowania stażu po uzyskaniu stopnia naukowego doktora na podstawie decyzji numer DEC-2013/08/S/HS3/00192 (projekt „Chronologia i kalendarze w kulturze umysłowej Europy Środkowej 1400-1700”). 
being introduced into manuscript circulation through correspondence and numerous copies, while at the same time serving as the basis for the creation of vernacular traditions of the text. These processes are depicted in source materials annexed to the paper, containing editions of accounts in Latin, Polish, and German.

Słowa kluczowe: Jerzy Joachim Retyk (1514-1574), Andrzej Dudycz (1533-1589), astrologia renesansowa, obieg rękopiśmienny - XVI i XVII w., propaganda polityczna - XVI i XVII w.

Keywords: Georg Joachim Rheticus (1514-1574), Andreas Dudithius (1533-1589), Renaissance astrology, manuscript circulation $-16^{\text {th }}$ and $17^{\text {th }}$ century, political propaganda $-16^{\text {th }}$ and $17^{\text {th }}$ century

\section{W s t ęp}

Wśród znajdujących się obiegu rękopiśmiennym doby staropolskiej krótkich utworów łączących $\mathrm{w}$ sobie tematykę polityczną z tradycją astrologiczną mało który tekst może poszczycić się tak dużą ilością bardzo różnych pod względem formy i treści przekazów co tzw. przepowiednia elekcyjna. Przyjmuje się, że pierwotna postać tekstu, niezachowana do dzisiejszych czasów w postaci autografu, została sporządzona przez astrologa, astronoma, matematyka i lekarza Jerzego Joachima Retyka (1514-1574) ${ }^{1}$. Uczony ten w latach 1554-1574 mieszkał w Krakowie i poprzez otoczenie wielkorządcy krakowskiego Jana Bonera (1516-1562) oraz kontakty nawiązane z Andrzejem Dudyczem (1533-1589), cesarskim dyplomatą, wywiadowcą i humanistą, znalazł się w pobliżu dworu królewskiego i prawdopodobnie z inicjatywy któregoś z tych trzech ośrodków: związanego z Zygmuntem Augustem, Bonerem lub Dudyczem, sporządził astrologiczny prognostyk, w którym nakreślił poczet przyszłych władców Rzeczypospolitej ${ }^{2}$.

${ }^{1} \mathrm{Na}$ temat Retyka zob.: K. H. Burmeister, Georg Joachim Rhetikus 1514-1574. Eine Bio-Bibliographie, Bd. 1-3, Wiesbaden 1968; L. Hajdukiewicz, Retyk Jerzy Joachim, PSB, 21, 1988, s. 255-259; D. Danielson, The First Copernican. Georg Joachim Rheticus and the Rise of the Copernican Revolution, New York 2006; J. Włodarczyk, Wstęp, w: J. J. Retyk, Relacja pierwsza z ksiag „O obrotach” Mikotaja Kopernika, tł. I. Lewandowski, wstęp i koment. J. Włodarczyk, Warszawa 2015, s. 7-68.

$2 \mathrm{Na}$ temat przepowiedni elekcyjnej zob. L. A. Birkenmajer, Mikotaj Kopernik. Częśc I: Studya nad pracami Kopernika oraz materyaty biograficzne, Kraków 1900, s. 613-614; J. Dianni, Pobyt J. J. Retyka w Krakowie, „Studia i Materiały z Dziejów 
Wkrótce po powstaniu tekst ten zaczął funkcjonować niezależnie od osoby autora, w różnych postaciach i w bardzo zróżnicowanych kontekstach, a jego kopie można odnaleźć obecnie w zbiorach bibliotecznych od Gdańska do Rzymu i od Berlina po Lwów. To wysokie zróżnicowanie tradycji rękopiśmiennej i geograficzne rozproszenie przekazów, które - jak wskazują na to cechy proweniencyjne rękopisów, w których się zachowały - były dystrybuowane nie tylko na terytorium Rzeczypospolitej, ale także poza jej granicami, stało się przyczyną wielu nieporozumień związanych z tym, jak wygląda archetypiczna postać Retykowego horoskopu elekcyjnego, w jakich okolicznościach powstała, czy mogła być faktycznie dziełem tego uczonego i jak należy postrzegać relacje pomiędzy postacią archetypiczną a przekazami znanymi z odpisów pochodzących z końca wieku XVII i początku XVIII ${ }^{3}$. Niniejsze studium ma trojaki cel: po pierwsze, omówienie najpełniejszego tekstu Retyka w świetle najbardziej miarodajnych przekazów horoskopu, następnie przedstawienie gałęzi składających się na tradycję rękopiśmienną przepowiedni elekcyjnej i wreszcie - udokumentowanie kilku wariantów tego tekstu, od próby rekonstrukcji archetypu aż po odmiany wernakularne, które zostały zawarte w aneksach źródłowych.

2. Horoskop a przepowiednia elekcyjna

Wydaje się, że wbrew obiegowemu określeniu, które wiąże tekst Retyka z korpusem tekstów popularnych, skierowanych do szerokiego grona mniej doświadczonych czy wyrobionych odbiorców, ten krótki utwór autora Narratio prima wywodzi się z nader wyrafinowanych pod względem technicznym i intelektualnym źródeł, a swój

Nauki Polskiej”, 1, 1953, s. 64-80; K. H. Burmeister, op. cit., Bd. 2, s. 23-28, Bd 3, s. 171, 193-200; J. Nowak-Dłużewski, Bibliografia staropolskiej okolicznościowej poezji politycznej (XVI-XVIII), Warszawa 1964, s. 3; T. Przypkowski, Astronomia $i$ astrologia $w$ Krakowie $w$ drugiej potowie XVI wieku, w: Historia astronomii $w$ Polsce, t. 1, red. E. Rybka, Wrocław 1975, s. 198; H. Barycz, Krakowski pobyt Jerzego Joachima Retyka, w: idem, Między Krakowem a Warmia i Mazurami, Olsztyn 1987, s. 169-212; A. T. Klubiński, Diversi color-kariera przepowiedni elekcyjnej (1697-1764), „Barok”, 5, 1998, z. 1, s. 225-233; Staropolskie przepowiednie i mirabilia, oprac. J. Kroczak, Wrocław 2007, s. 168, przyp. 187. Odnośnie do krytycznego omówienia powyższych stanowisk zob. M. Choptiany, "Ultra prognosticare me sidera non permittunt”. O astrologicznych źródtach przepowiedni elekcyjnej Jerzego Joachima Retyka, „Kwartalnik Historii Nauki i Techniki”, 61, 2016, nr 4, w druku.

3 Por. M. Choptiany, op. cit. 
początek bierze z faktycznej praktyki astrologicznej opartej na obserwacjach astronomicznych, procedurach obliczeniowych i zastosowaniu do nich regut interpretacyjnych ${ }^{4}$. W świetle przeprowadzonej na potrzeby niniejszego studium analizy 28 przekazów w języku łacińskim, polskim i niemieckim można $\mathrm{z}$ dużym prawdopodobieństwem stwierdzić, iż oryginalny tekst Retyka miał w rzeczywistości postać horoskopu składającego się z diagramu, w którym w schematyczny sposób przedstawione zostały astrologiczno-astronomiczne parametry - położenie planet, Słońca i Księżyca względem dwunastu znaków zodiaku w momencie interrogacji, oraz komentarza zawierającego wyjaśnienie. W kontekście politycznym tego rodzaju horoskopy były sporządzane przede wszystkim z okazji narodzin królewskiego lub książęcego potomka, przy okazji kolejnych rocznic urodzin władcy lub w związku z doniosłymi z punktu widzenia państwa wydarzeniami, jednak procedury heurystyczne astrologii miały o wiele szersze zastosowanie i użycie ich do wybiegającej daleko w przyszłość prognozy mieściło się $\mathrm{w}$ granicach kanonu renesansowej astrologii ${ }^{5}$.

W wypadku horoskopu elekcyjnego przypisywanego Retykowi na komentarz złożyły się informacje dotyczące zadania postawionego astrologowi oraz szczegółowe informacje na temat okoliczności, w jakich horoskop został sporządzony. Pytanie, jakie zadał sobie uczeń Kopernika, dotyczyło przetrwania królestwa, nad którym pieczę sprawował Zygmunt August, oraz tego, jakimi cechami będą się odznaczać przyszli władcy Rzeczypospolitej i czy któryś

4 Rekonstrukcję warunków i metod pracy szesnastowiecznego astrologa podaje A. Grafton, Cardano's Cosmos. The Worlds and Works of a Renaissance Astrologer, Cambridge (Mass.)-London 2001, rozdz. 2: „The Astrologer's Practice” (s. 22-37). Na temat astrologii po Koperniku zob. R. S. Westman, The Copernican Question. Prognostication, Skepticism, and Celestial Order, Berkeley-Los Angeles-London 2011. O astrologicznych aspektach spuścizny Retyka zob.: K. H. Burmeister, op. cit., Bd. 3, s. 166-172; J. Kraai, Rheticus' Heliocentric Providence. A Study Concerning the Astrology and Astronomy of the Sixteenth Century, rozprawa doktorska, Universität Heidelberg, 2001, http://www.ub.uni-heidelberg.de/ archiv/3254 (12 V 2016).

5 Na temat typów horoskopów zob.: E. Śnieżyńska-Stolot, „Zamek piękny na wzgórzu...". Horoskopy - zapomniane źródto historyczne, Kraków 2015, s. 23-35; J. D. North, Horoscopes and History, London 1986. Dla omówienia problemów związanych z interpretacją diagramów horoskopowych (na przykładzie genitur, tj. horoskopów urodzinowych) zob. M. Azzolini, Refining the Astrologer's Art. Astrological Diagrams in Bodleian MS Canon. Misc. 24 and Cardanos "Libelli Quinque” (1547), „Journal for the History of Astronomy”, 42, 2011, 1, s. $1-25$. 
z nich okaże się lepszy od ostatniego Jagiellona. Po takim sformułowaniu zadania następowała najprawdopodobniej słowna interpretacja informacji zawartych w diagramie: oprócz pozycji planet $\mathrm{w}$ znakach zodiaku (podawanych w stopniach) ujęte zostały informacje dotyczące zależności pomiędzy ciałami niebieskimi a poszczególnymi domami - te bowiem miały istotne znaczenie dla całościowej wymowy horoskopu. $\mathrm{Na}$ dalszą część najpełniejszej wersji horoskopu elekcyjnego złożył się szereg charakterystyk władców, mających formę skrótowych narracji poświęconych przebiegowi ich panowania: od odznaczającego się prawością i pobożnością księcia panującego bardzo krótko, przez kolejnych monarchów. Wśród nich znalazł się zbrodniczy, surowy i zachłanny starzec, którego panowanie miało być naznaczone smutkiem, doświadczony w boju młodzieniec, choć jego rządom nie przypisano większego znaczenia, a sam władca miał prawdopodobnie polec $\mathrm{w}$ bitwie. Horoskop zapowiadał też nadejście władcy wywodzącego się ze znamienitego rodu, pod jego rządami miały zapanować sprawiedliwość i pokój. W poczcie przyszłych panujących znalazło się również miejsce dla królowej i z jej panowaniem miało się wiązać krótkotrwałe przeobrażenie republiki szlacheckiej (respublica) w oligarchię. Cały wywód, obejmujący łącznie osiem charakterystyk, zamykało stwierdzenie astrologa, jakoby więcej nie mógł już odczytać z danych zgromadzonych w trakcie sporządzania horoskopu 6 .

Ten krótki astrologiczno-polityczny utwór autora Relacji pierwszej bardzo szybko przedostał się do szerszego obiegu i służył już nie tylko jako popularna ciekawostka, pozwalająca piśmiennym mieszkańcom Rzeczypospolitej przekonać się, co astrologowi „znaki prognostykować dopuściły"7 $\mathrm{i}$ „weryfikować" te twierdzenia poprzez dopisywanie post factum imion władców przy kolejnych bardzo ogólnych - a przez to podatnych na dokonywane z różnych punktów widzenia odczytania charakterystykach, ale także jako jedno z narzędzi kształtowania opinii w okresie następującym bezpośrednio po śmierci ostatniego Jagiellona, podczas pierwszego i drugiego bezkrólewia, ale także w stuleciu XVII i w pierwszej połowie wieku XVIII. To wieloaspektowe odczytywanie sensu horoskopu i jego funkcjonalność oraz wyrosła z niego

${ }^{6}$ Dla edycji przekazów składających się na najpełniejszą wersję tekstu horoskopu elekcyjnego zob. aneks 1.

7 Trawestuję w tym miejscu zakończenie przepowiedni elekcyjnej z przekazu $K c$; sigla wszystkich przekazów oraz ich charakterystyki znajdują się w cz. 3 niniejszego studium, natomiast edycja całego przekazu $K c$ zawarta została w aneksie 3. 
popularna przepowiednia przyczyniły się w dużej mierze do znacznego rozmnożenia wariantów tekstowych, w wyniku czego rodzina utworów określanych w literaturze przedmiotu mianem „przepowiedni elekcyjnej" obejmuje zarówno teksty zawierające bardzo rozbudowany (choć nie zawsze poprawny) aparat astrologiczny, potwierdzający pierwotną "gwiazdarską" proweniencję tekstu wyjściowego, jak również teksty wadliwe i zubożone, podające wykładnie astrologiczną w sposób błędny lub całkowicie jej pozbawione. Nie jest to jedyna różnica nastręczająca dużych trudności związanych z uporządkowaniem i klasyfikacją poszczególnych wariantów. Niektóre bowiem przekazy cechują się dosyć rozbudowanymi, niemal narracyjnymi charakterystykami władców, podczas gdy inne składają się z lapidarnych wyliczeń; pomiędzy wieloma przekazami brakuje również zgody co do kolejności poszczególnych charakterystyk. Te ostatnie były również częstokroć przedmiotem daleko idących ingerencji kopistów, którzy radykalnie modyfikowali ich wymowę.

\section{Zidentyfikowane przekazy Vaticinium}

Dla przeprowadzonych przeze mnie poszukiwań punkt wyjścia stanowiło zestawienie sporządzone w latach sześćdziesiątych ubiegłego stulecia przez Karla-Heinza Burmeistra ${ }^{8}$. Szybko okazało się jednak, że niektóre z wymienionych przez biografa Retyka rękopisów nie są już dzisiaj dostępne, inne z kolei nie zostały w ogóle przez niego wzięte pod uwagę. Według dzisiejszego stanu wiedzy lista rękopisów zawierających różne odmiany tekstu Retyka, powstałe od XVI do XVIII w., przedstawia się następująco":

\section{Przekazy zachowane \\ Tekst taciński}

$B$ Berlin, Staatsbibliothek, Ms. germ. fol. 143, k. 437rec.: Judicium Rhetici Doctoris Medicinae, astronomi peritissimi, de Electione regum Poloniae, factum post obitum Regis Sigismundi, Anno $[15] 71$.

K. H. Burmeister, op. cit., Bd. 2, s. 23-28.

9 Poniższe zestawienie zostało opublikowane w postaci aneksu w: M. Choptiany, op. cit. W tym miejscu zostaje ono jednak poszerzone o przytoczone in extenso tytuły poszczególnych przekazów oraz krótkie charakterystyki poszczególnych kodeksów, w ramach których wskazany jest ich format, datowanie, ogólna charakterystyka zawartości, proweniencja (tam, gdzie było to możliwe) oraz adres katalogu, w którym można znaleźć bardziej szczegółowe informacje. 
Kopiariusz in folio zawierający pisma polityczne, dokumenty i teksty okolicznościowe dotyczące Rzeszy i Rzeczypospolitej, XVI- XVII w. ${ }^{10}$

C Città del Vaticano, Bibliotheca Apostolica Vaticana, Ottob. lat. 2642, k. 94rec.: Vaticinium Georgii Rhetici Medicinae Doctoris et Astronomi, de electione Regum Poloniae scriptum post obitum Sigismundi Augusti Regis Anno M.D.LXXI.

Kodeks in folio, XVII w., zawiera Diarium electionis Polonicae anno 1587 oraz zapiski dotyczące elekcji z roku 1697.

Da Gdańsk, Biblioteka Gdańska PAN, Ms. 694, k. 201 rec.-202ver.: Vaticinium Anno 1551 Betij Retycij Doctoris et Astrologi Doctissimi, Medici, de Regnatione Regni Poloniae post decessum Sigismundi Augusti. Kopiariusz in folio z XVII w., zawiera pisma polityczne, dokumenty i teksty okolicznościowe dotyczące Gdańska i relacji Prus Królewskich z Rzecząpospolitą ${ }^{11}$.

Db Gdańsk, Biblioteka Gdańska PAN, Ms. 724, k. 109ver.: Vaticinium Anno 1551 Betij Retici Doctoris et Astrologi Doctissimi Medici De Regnatione Regni Poloniae post decessum Sigismundi Augusti. Kopiariusz in folio z przełomu XVII i XVIII w., zawiera pisma polityczne, dokumenty i teksty okolicznościowe dotyczące Gdańska, Prus Królewskich oraz Rzeczypospolitej, kodeks z biblioteki Daniela Gralatha ${ }^{12}$.

Dc Gdańsk, Biblioteka Gdańska PAN, Ms. 821, k. 2rec.: Vaticinium $D$ [omini] Rhetici Medici et Astronomi peritissimi de Electione et Gubernatione Regum Poloniae, factum ante Obitum D. Sigismundi Augusti Anno 1571.

Kopiariusz in folio z końca XVII w., zawiera odpisy przywilejów królewskich dla Gdańska ${ }^{13}$.

${ }^{10}$ Zob. H. Degering, Kurzes Verzeichnis der germanischen Handschriften der Preussischen Staatsbibliothek, Bd. 1: Die Handschriften in Folioformat, Leipzig 1925, s. 19-21.

${ }_{11}$ Zob. O. Günther, Katalog der Danziger Stadtbibliothek, Bd. 1, Theil 1: Die Danzig betreffenden Handschriften, Danzig 1892, s. 435-444.

12 Zob. ibidem, s. 495-525.

13 Zob. O. Günther, Katalog der Danziger Stadtbibliothek, Bd. 1, Theil 2, Danzig 1903, s. 26-27. 
Dd Gdańsk, Biblioteka Gdańska PAN, Ms. Uph. fol. 26, s. 243: Responsum Joachimi Mathematici doctissimi ad quaesitum Sigismundi Augusti Regis Poloniae utrum regimen suum sit diuturnum et an sub alio gubernatio melior feliciorq [ue] duratura.

Kopiariusz in folio z XVI i XVII w., zawiera odpisy dokumentów i tekstów związanych z relacjami Gdańska i Prus Królewskich z Rzecząpospolitą ${ }^{14}$.

Fb Kórnik, Biblioteka Kórnicka PAN, rkps 341, k. 185rec.-ver.: Quaestio utru[m] Regnu[m] istius Principis duraturum item an sub alio melior foret gubernatio Anno D[omini] M.D.L.XIII

Fc Kórnik, Biblioteka Kórnicka PAN, rkps 341, k. 186rec.: Vaticinium Bethaci Doctoris et Astronomi promptissimi Mediciq[ue] excellentissimi Anno D[omini]1507. De Regnatione Regem Poloniae post decessum Sigismundi Augusti Regis Polonorum

Kopiariusz z XVII-XVIII w., zawiera odpisy pism politycznych, korespondencji i diariuszy sejmowych z XVII w. oraz m.in. antyjezuicki dialog satyryczny Gratis Jana Brożka.

Fd Kórnik, Biblioteka Kórnicka PAN, rkps 352, k. 135ver.: Vaticinium Reticii doctoris et astrologi doctissimi medici $A[n n]$ o $D[o m i] n i$ 1502 De regnatione Regni Poloniae post decessum Sigismundi Augusti Regis Poloniae.

Kopiariusz zawierający odpisy dokumentów, listów i utworów okolicznościowych z lat pięćdziesiątych XVII w.

Ka Kraków, Biblioteka Jagiellońska, rkps 118, s. 235-237: Prognosticon Regum Polonorum quoru[n]dam.

Kb Kraków, Biblioteka Jagiellońska, rkps 118, s. 445: Vaticinium ex parte regum septem post decessum Sigismundi Augusti per Rheticum doctorem et astrologum medicum illustrem editum.

Kopiariusz in folio, dzieło kilku rąk z XVI i XVII w., zawiera szereg pism z okresu panowania Zygmunta Augusta, Stefana Batorego i Zygmunta III Wazy ${ }^{15}$.

14 Zob. ibidem, s. 392-396.

15 Zob. W. Wisłocki, Katalog rękopisów Biblijoteki Uniwersytetu Jagiellonskiego, cz. 1: Wstęp. Rękopisy 1-1875, Kraków 1877, s. 49. 
La Kraków, Biblioteka XX. Czartoryskich, rkps 1292, s. 8: Vaticinium Rethici doctoris medici et astronomiae de electione regum Polonie statim factum post obitum regis Sigismundi Augusti anno Domini 1571.

Kodeks in octavo z pierwszej połowy XVI w. - zawiera odpisy statutów biskupa krakowskiego Jana V Lutka z Brzezia (1405-1471) oraz arcybiskupa gnieźnieńskiego Jana Łaskiego (1456-1531), tekst Vaticinium umieszczony na wolnej stronie pomiędzy odpisami ${ }^{16}$.

Lb Kraków, Biblioteka XX. Czartoryskich, rkps 1657 IV, s. 596 (= k. 446ver.): Judicium D[omi]ni Gregorij Rethen Astronomiae peritissimi de electione Polon[orum] Regum A[nn] 1571 editu[m]. Kopiariusz in folio z drugiej połowy XVII w., zawiera odpisy dokumentów, listów oraz tekstów okolicznościowych dotyczących Rzeczypospolitej pod panowaniem Wazów ${ }^{17}$.

Lc Kraków, Biblioteka XX. Czartoryskich, rkps 1947 III, s. 50: Prognostic Retici Doctoris et Astrologi Doctissimi AD 1601 De regnatione Regum Poloniae.

Kopiariusz in folio z drugiej połowy XVII w., zawiera odpisy dokumentów podatkowych, listów politycznych i pogrzebowych, mów i pism politycznych; proweniencja: Mazowsze, okolice Raciąża ${ }^{18}$.

$M$ Lwów, Biblioteka Naukowa im. W. Stefanyka, fond 5, rkps 189 (olim Lwów, Biblioteka Zakładu Narodowego im. Ossolińskich, rkps 189/II), s. 8: Judicium Rethici Doctoris Medicine et Astronomie peritissimi De Electione Reg[u]m Polonorum facta post obitum 1552. Obszerny kodeks in folio z drugiej połowy XVII w., wykonany w znacznej mierze przez Marcina Golińskiego, zawiera odpisy dokumentów, listów oraz tekstów okolicznościowych dotyczących okresu od lat czterdziestych do sześćdziesiątych XVII w., oprócz tego w kodeksie kilkanaście innych prognostyków, głównie odnoszących się wprost do okresu powstania kodeksu ${ }^{19}$.

16 S. Kutrzeba, Catalogus codicum manu scriptorum Musei Principum Czartoryski Cracoviensis, vol. 2, Cracoviae 1913, s. 160.

17 Por. ibidem, s. 324-335.

18 Zob. Katalog rękopisów Biblioteki Czartoryskich w Krakowie. Sygnatury 1682-2000, oprac. M. Kukiel, uzup. A. Homecki, Kraków 1988, s. 234-236.

19 Por. W. Kętrzyński, Katalog rękopisów Biblioteki Zaktadu Narodowego im. Ossolińskich, t. 1, Lwów 1881, s. 439-457. 
$N$ Milano, Biblioteca Ambrosiana, D 208 inf., k. 170rec.-171rec.: Reticus Medicus et Astrologus Cracoviensis, Quaestio utrum istius Principis est diu duraturum Imperium an sub alio melior futura gubernatio Anno MDLXIII 1 die aprilis hora 1, minut[orum] 15 post meridiem, poli elevatio 51.

Kodeks in folio z końcówki XVI w., zawiera odpisy dokumentów, listów oraz tekstów okolicznościowych dotyczących spraw politycznych i wyznaniowych w okresie pierwszego i drugiego bezkrólewia; tom z biblioteki Gian Vincenza Pinellego (1535-1601).

Rb Warszawa, Biblioteka Narodowa, rkps 6647 II, k. 267ver.-268rec.: Praedictio cuiusdam viri Graecii medicinae et astrologiae peritissimi de futuris Reipublicae Poloniae facta per obitum Sigismundi Augusti Anno 1572.

Kopiariusz in quarto materiałów historycznych i publicystyczno-literackich dotyczących bezkrólewia po Janie III i elekcji Augusta II, proweniencja: Archiwum Morstinów ${ }^{20}$.

$V$ Wrocław, Biblioteka Uniwersytecka, rkps Akc. 1949/594, k. 56ver.-57ver.: Iudicium D[omi]ni Georgii Ioachimi Rhaetici, medici et astronomi peritissimi, de successoribus in regno Poloniae post obitum regis Sigismundi II. Anno 1571.

Pochodzący z XVIII w. odpis (niezachowanego) rękopisu nr 375 z biblioteki kościoła Marii Magdaleny we Wrocławiu (Rehdigeriany) $)^{21}$.

Wa Wrocław, Biblioteka Zakładu Narodowego im. Ossolińskich, rkps 190/II, k. 9ver.: Vaticinium Retici Doctoris peritissimi phisici mediciq[ue] ill[ustrissi]mi ducis Slucensis Georgii Philosophiae magistri de electione regum Poloniae factum post obitum Serenissimi Sigismundi Augusti Regis Poloniae Anno 1572.

Kodeks z XVII w., dzieło kilku rąk, zawiera kopie pism i dokumentów związanych z rokoszem Zebrzydowskiego ${ }^{22}$.

20 Zob. Katalog rękopisów Biblioteki Narodowej, t. 7: Rękopisy 6601-7000. Zbiory Morstinów, Radziwittów, Potockich i inne rękopisy XVI-XVIII w., red. K. Muszyńska, Warszawa 1969, s. 114-124.

21 Na temat oryginalnego rękopisu zob. M. A. Guttmann, Katalog der Handschriften der Rehdigerana, Abt. 1, s. 80 (katalog w formie rękopisu, Wrocław, Biblioteka Uniwersytetu Wrocławskiego, rkps Akc. 1967/3).

22 Por. W. Kętrzyński, op. cit., s. 457-463. 
Wb Wrocław, Biblioteka Zakładu Narodowego im. Ossolińskich, rkps 200/II, k. 208rec.-ver.: Vaticinium Doctoris est Astronomi peritissimi Regij A[nn] 1552 D[omini] de Regnatione Regum Poloniae post decessum Sigismundi Augusti.

Kodeks z przełomu XVII i XVIII w., dzieło kilku rąk, zawiera kopie listów, pism politycznych i tekstów okolicznościowych $\mathrm{z}$ tego okresu ${ }^{23}$.

Wc Wrocław, Biblioteka Zakładu Narodowego im. Ossolińskich, rkps 223/II, s. 5: Vaticinium Doctoris et Astronomi peritissimi Rhetici $A[n n]$ o 1552 de reg[nati]one Regum Poloniae post decessu[m] Sigism[un]di Augusti.

Kopiariusz z XVII w., dzieło kilku rąk, zawiera odpisy listów, pism i dokumentów dotyczących spraw wewnętrznych i międzynarodowych Rzeczypospolitej w pierwszej połowie XVII w. ${ }^{24}$

Wd Wrocław, Biblioteka Zakładu Narodowego im. Ossolińskich, rkps 3163/II, s. 20-21: Vaticinium Doctoris Astronomiae Perfectissimi Reiji de successione Regum Poloniae post obitum Sigismundi Augusti Anno D[omi]no 1552.

Osiemnastowieczny kopiariusz zawierający odpisy utworów literackich i pism politycznych dotyczących XVII i XVIII stulecia ${ }^{25}$.

\section{Tekst niemiecki}

De Gdańsk, Biblioteka Gdańska PAN, Ms. 907, s. 68: Vaticinium, oder Weissagung Doctoris Retzij de sehr erfahrnen Medici et Astronomi von den Wahl un Regierung der Könige zu Pohlen Geschehen fürm Tode Königs Sigismundi Augusti, Anno 1571.

Kodeks in folio, w języku niemieckim, XVII w., zawierający m.in. obszerne zestawienia dotyczące dawnych burmistrzów i członków rady miejskiej Gdańska ${ }^{26}$.

Df Gdańsk, Biblioteka Gdańska PAN, Ms. 1293, k. 157ver.-158ver.: Weisagung Doctoris Joannis Rezy ... von der wahl und Regierung der Könige zu Pohlen.

23 Por. ibidem, s. 497-508.

24 Por. ibidem, s. 595-600.

25 Inwentarz rękopisów Biblioteki Zaktadu Narodowego im. Ossoliniskich we Wroctawiu, t. 1: Rękopisy 1505-7325, red. J. Turska, Wrocław 1948, s. 152.

26 Zob. O. Günther, op. cit., Bd. 1, Theil 2, s. 59. 
Kodeks in folio, w języku niemieckim, XVII w., zawierający m.in. kopie przywilejów nadanych miastu Gdańsk oraz materiały historyczne dotyczace miasta ${ }^{27}$.

Fa Kórnik, Biblioteka Kórnicka PAN, rkps 169, k. 13ver.-14rec.: Weissagung doctoris Ratzii von der Wahl unnd Regierung der Könninge von Pohlenn geschehen kurz fürm Tode selig Könning Sigismundi anno 1571.

Kodeks z XVII w. zawierający pisma Bartholomeusa Wartzmanna i kilka przepowiedni o charakterze politycznym.

Tekst polski

$\mathrm{Fe}$ Kórnik, Biblioteka Kórnicka PAN, rkps 420, k. 247ver.-248rec.: Prognostyk astronoma krakowskiego Rescyusza o Successyi Krolow Polskich, po Smierci Augusta Pierwszego Krola Polskiego w Roku 1552. Kodeks z początku XVIII w. zawierający dokumenty związane z konfederacją tarnogrodzką (1715-1716).

Kc Kraków, Biblioteka Jagiellońska, rkps 921, k. 1rec.-ver.: Wyttumaczenie z tacinskiego na polski jezzyk Prognostyku przez niegdy Geciusza nazwanego doktora o następujących królach polskich, $z$ manuskryptu wypisane.

Pojedyncza, dwustronnie zapisana karta z XVIII w. (dissolutum pochodzące $\mathrm{z}$ sylwy z tego okresu? $)^{28}$.

Ra Warszawa, Biblioteka Narodowa, rkps 6634 III, k. 207rec.: Praktika doctoris Klitricii za panowania króla Zygmu[nta] Augusta uczyniona. Kodeks in folio z połowy XVII w., zawiera odpisy materiałów literackich i dokumentów historycznych z pierwszej połowy XVII stulecia, własność Jakuba Michałowskiego (1612-1663), następnie Archiwum Morstinów ${ }^{29}$.

\section{Przekazy zaginione \\ Tekst tacinski}

Dh Gdańsk, Biblioteka Gdańska PAN, Ms. 781, k. 44rec.-45ver.: Vaticinium Doctoris Rhetici.

27 Zob. ibidem, s. 225-227.

28 Zob. W. Wisłocki, op. cit., s. 260.

29 Zob. Katalog rękopisów Biblioteki Narodowej, t. 7, s. 46-53. 
Strata wojenna zidentyfikowana po 1945 r., kodeks w języku łacińskim i niemieckim, XVII w., kopiariusz z dokumentami i pismami okolicznościowymi związanymi z Gdańskiem i stosunkami Prus Królewskich z Rzecząpospolitą ${ }^{30}$.

$S$ Weimar, Herzogin Anna Amalia Bibliothek, sygn. 30,6:18: Judicium Joachimi Rhetici ... de electione regum Poloniae factum post obitum Sigismundi a[nno] 1571.

Rękopis utracony w wyniku pożaru w 2004 r. Pozycja 19. w liczącym 22 jednostki klocku introligatorskim składającym się z kilku rękopisów i kilkunastu druków m.in. o tematyce astrologicznej i astronomicznej. Według opisu katalogowego rękopis Judicium zajmował jedną kartę ${ }^{31}$.

\section{Tekst niemiecki}

Dg Gdańsk, Biblioteka Gdańska PAN, Ms. 675, k. 325: Weissagung Dr. Rhaetici von der Wabl und Regierung der Könige zu Pohlen. Strata wojenna zidentyfikowana po 1945 r. Kodeks powstały w XVI-XVII w., w XVIII w. własność Walentego Schlieffa (1680-1750), kopiariusz zawierający listy i dokumenty, głównie te związane z sytuacją polityczną Gdańska i relacjami miasta z Rzecząpospolitą i Szwecją ${ }^{32}$.

Di Gdańsk, Biblioteka Gdańska PAN, Ms. Uph. fol. 47, k. 56: Weissagung Doctoris Joannis Rezij.

Strata wojenna zidentyfikowana po 1945 r. Kodeks z XVII w., kopiariusz przywilejów nadanych miastu Gdańsk ${ }^{33}$.

Dj Gdańsk, Biblioteka Gdańska PAN, Ms. Uph. fol. 191, s. 142: Rhetici Weisagung.

Strata wojenna zidentyfikowana po 1945 r. Autograf gdańskiego historyka Andreasa Schotta (1707-1764) pochodzący z 1747 r., kolekcja wypisów do historii Gdańska i Prus Królewskich ${ }^{34}$.

30 Por. opis kodeksu w: O. Günther, op. cit., Bd. 1, Theil 1, s. 605-607.

31 Zob. Verlust- und Schadensdatenbank der Herzogin Anna Amalia Bibliothek, www.anna-amalia-bibliothek.de/de/verlustdatenbank.html (12 V 2016).

32 Por. opis kodeksu w: O. Günther, op. cit., Bd. 1, Theil 1, s. 384-387.

33 Por. opis kodeksu w: ibidem, Theil 2, s. 408.

34 Zob. ibidem, s. 463-464. 
Dokładna analiza tych przekazów potwierdziła główną intuicję Burmeistra, a mianowicie, że przekaz pochodzący z Wrocławia (rękopis $V$ ) zawiera jeden z tekstów, dzięki którym najlepiej można zrozumieć istotę tego, czym był astrologiczno-polityczny utwór Retyka. Porównanie $V$ z innymi przekazami ujawniło jednak również bliskie powiązanie tego przekazu z kilkoma innymi rękopisami, a także umożliwiło uporządkowanie tekstów w sposób pozwalający na stworzenie modelu pokazującego kolejne przekształcenia tego utworu. Zgromadzony materiał źródłowy pozwala na odtworzenie pewnego ogólnego zarysu rozwoju tego tekstu i zakorzeniania się go w popularnym rejestrze dyskursu politycznego związanego z władcami elekcyjnymi, jednak nie ma on z całą pewnością charakteru wyczerpującego i ostatecznego. Należy się liczyć zarówno z możliwością odnalezienia samego autografu Retyka, jak i - co o wiele bardziej prawdopodobne - z faktem, iż w sylwach i kopiariuszach, do których nie udało mi się dotrzeć lub z których istnienia nie zdawałem sobie sprawy, znajdują się kolejne przekazy dające się przyporządkować do którejś ze wskazanych niżej grup lub w świetle których konieczna będzie w przyszłości cząstkowa rewizja poczynionych tutaj ustaleń. Tego rodzaju przyszłe emendacje nie powinny jednak zasadniczo zmienić faktu, że jednym z kluczowych dla całej rodziny tekstów jest przekaz wrocławski.

4. Przekaz $V-$ świadek koronny

Paradoksalnym wydawać się może fakt, iż przekaz, który daje nam najprawdopodobniej najlepszy wgląd w to, jak mógł wyglądać oryginalny horoskop elekcyjny Retyka, jest młodszy od samego tekstu o około dwa stulecia. Chociaż rękopisowi $V$ z punktu widzenia chronologii najbliżej do najbardziej zepsutych i odległych od archetypu pod względem formalnym i treściowym świadków Vaticinium, w których brak aparatu astrologicznego, a nazwisko autora - o ile jest w nich w ogóle przytaczane - zostało całkowicie zniekształcone, to wiele czynników wskazuje na to, że to właśnie ten rękopis należy uznawać za o wiele bardziej wiarygodny od niektórych kopii sporządzonych w XVI stuleciu, czyli jeszcze za życia lub kilka lat po śmierci Retyka.

Przekaz $V$ powstał w XVIII w. jako kopia kodeksu nr 375, który znajdował się w zbiorach wrocławskiej biblioteki kościoła Marii Magdaleny i został sporządzony przez Samuela Beniamina Klosego (1730-1798), wybitnego śląskiego dziejopisarza doby 
oświecenia ${ }^{35}$. Książnica ta powstała na bazie zbiorów patrycjusza Thomasa Rehdigera (1540-1576), humanisty i bibliofila aktywnego na arenie intelektualnej Wrocławia, a do kręgu rodziny Rehdigerów, w szczególności do bankiera i kupca Nicolausa Rehdigera młodszego (1525-1587), brata Thomasa, zbliżył się Dudycz, kiedy osiedlił się we Wrocławiu po wyborze Stefana Batorego na króla Polski ${ }^{36}$. To właśnie we Wrocławiu stworzył w ostatnim okresie swojego życia krąg intelektualistów-erudytów, do którego zaliczali się m.in. astronom i astrolog Tadeáš Hájek oraz medyk i humanista Johann Crato von Krafftheim. W przeciwieństwie do księgozbioru Dudycza, rozproszonego już na początku XVII w. i fragmentarycznie zachowanego w zbiorach wrocławskich ${ }^{37}$, znaczna część rękopisów dokumentujących życie intelektualne jego kręgu zachowała się na Śląsku, właśnie w zbiorach Rehdigeriany, które następnie zostały wchłonięte przez Bibliotekę Uniwersytecką we Wrocławiu. Prawdopodobnie to właśnie znaczenie postaci samego Dudycza i fakt, że zapisał się wyraziście w dziejach szesnastowiecznego Wrocławia sprawiły, że Klose, w ramach szeroko zakrojonego przedsięwzięcia polegającego na zgromadzeniu wypisów i charakterystyk źródeł do dziejów Śląska i jego stolicy, postanowił wykonać odpis tych dokumentów, w tym znajdującego się między nimi tekstu Retyka ${ }^{38}$. Kodeks, w którym zachował się przekaz $V$, stanowi również jeden z szeregu przykładów źródeł, które w oryginalnej postaci nie zachowały się do czasów nam współczesnych i do których dostęp mamy wyłącznie dzięki staraniom Klosego ${ }^{39}$.

35 Na temat Klosego zob. L. Harc, Samuel Beniamin Klose (1730-1798). Studium historiograficzno-źródtoznawcze, Wrocław 2002 (Acta Universitatis Wratislaviensi; 2389 - Historia, 157).

36 Zob. G. Almási, The Uses of Humanism: Johannes Sambucus (1531-1584), Andreas Dudith (1533-1589), and the Republic of Letters in East Central Europe, Leiden-Boston 2009, s. 76-77; na temat Rehdigera i jego biblioteki zob. D. Haberland, Thomas Rehdiger - Humanist, Sammler und Begründer der Breslauer Stadtbibliothek, w: Slaska Republika Uczonych / Schlesische Gelehrtenrepublik / Slezská védecká obec, t. 4, red. M. Hałub, A. Mańko-Matysiak, Wrocław 2010, s. 73-112.

37 Por. Dudith András könyvtára. Részleges rekonstrukció, összeállította és az előszót írta J. Jankovics, I. Monok, Szeged 1993, s. 9.

38 Zob. L. Harc, op. cit., s. 118-132. Liczące przeszło 200 jednostek archiwum Klosego znajduje się obecnie w dwóch wrocławskich instytucjach: Archiwum Państwowym oraz Oddziale Rękopisów Biblioteki Uniwersyteckiej; zob. ibidem, s. 259 .

39 Ibidem, s. 131-132. 
Wieloletnia zażyłość Dudycza z Retykiem, rozległa działalność korespondencyjna pierwszego z nich oraz - przygodny w gruncie rzeczy - fakt lokalizacji $V$ we Wrocławiu nie stanowią jeszcze wystarczających powodów do przyznania pierwszeństwa temu właśnie przekazowi, choć umożliwiają rekonstrukcję kontekstu, w jakim pierwsza wersja Vaticinium była wprowadzana do obiegu. Istnieje wszakże szereg cech samego rękopisu $V$, które przemawiają za twierdzeniem, że to właśnie ten przekaz daje nam dzisiaj uprzywilejowany - choć obarczony marginesem niepewności - dostęp do niezachowanego archetypu.

1. Tekst $V$ jest najdłuższym ze wszystkich znanych przekazów tekstem Vaticinium i choć jego poszczególne części korespondują strukturalnie z późniejszymi lapidarnymi wersjami Vaticinium, mają w wypadku $V$ rozbudowany charakter, natomiast leksyka jest łatwa do zidentyfikowania nawet $\mathrm{w}$ stosunkowo późnych i zniekształconych przekazach.

2. W narracji o przyszłych władcach Polski pojawiają się elementy aparatu pojęciowego astrologii: omówione są pozycje słońca, księżyca oraz planet, a z nich następnie wyciągnięte wnioski natury historyczno-politycznej. Zachowanie w kolejnych segmentach tekstu $V$ informacji o charakterze astrologicznym pełni funkcję lectio dificilior: $\mathrm{w}$ porównaniu $\mathrm{z}$ innymi przekazami to ten jawi się jako najbardziej skomplikowany treściowo i wymagający zróżnicowanych kompetencji interpretacyjnych, a przez to wskazujący na autorstwo znającego się na swoim fachu astrologa, w tym wypadku zidentyfikowanego bezbłędnie w nagłówku tekstu Retyka.

3. Przekaz $V$ został wprowadzony przez Klosego do kodeksu bez dodatkowych wyróżnień, tekst zaczyna się na środku karty, co zapewne miało służyć zaoszczędzeniu miejsca. Na kolejnych marginesach znajdują się, sporządzone ręką wrocławskiego historyka, adnotacje na temat kalendarium życia śląskich humanistów przełomu XVI i XVII w., co stanowi dowód na to, że autor kopii miał świadomość historycznej wartości przepisywanych przez siebie dokumentów i że starał się wiernie oddawać i porządkować materiały, z którymi miał do czynienia. Sam sposób zapisu tekstu Retykowego horoskopu wskazuje na fakt, iż podstawa kopii miała charakter „profesjonalnego" astrologicznego rękopisu - w przekazie są stosowane symbole astrologiczne, które w innych wariantach najczęściej zastępują nazwy znaków zodiaku i ciał niebieskich. Co znamienne, jeden z przekazów zbliżonych do $V$, a mianowicie przekaz $N$, już od XVI w. 
znajdujący się w zbiorach mediolańskiej Ambrosiany, podaje w niektórych miejscach inne nazwy ciał niebieskich niż $V$ (planeta Mars zamiast znaku Lwa oraz Merkury zamiast znaku Byka), co dowodzi, jak bardzo szybko doszło do dezintegracji tekstu i pojawienia się w jego odpisach błędów.

4. Przekaz $V$ zawiera element nieobecny w innych rękopisach, a mianowicie diagram horoskopowy wystawiony na 1 kwietnia 1563 r., na godzinę 1:15 po południu. Sposób, w jaki skopiował go Klose, sprawia, że nie przypomina on swoją formą diagramów horoskopowych zawierających podział zodiaku na 12 domów w postaci przylegających do siebie trójkątów wpisanych w kwadrat ${ }^{40}$, jednak pojawia się w nim istotny element nieobecny w innych przekazach, a mianowicie precyzyjne dane czasowe opisujące okoliczności sformułowania pytania o jakość rządów następców Zygmunta Augusta. Można zatem przyjąć, że $V$ stanowi dowód na to, iż u źródła przepowiedni elekcyjnej nie leży żaden stylizowany na polityczne proroctwo tekst, ale sporządzony zgodnie z regułami astrologicznej sztuki horoskop zaopatrzony w komentarz, który w ciągu następnych dziesięcioleci kopiowania i przekazywania dalej oddzielił się od diagramu i zaczął niezależny tekstowy byt. W odniesieniu do tej kwestii warto tutaj odnotować, że o ile w niektórych sytuacjach przekaz $N$ wydaje się być błędny, tak akurat w wypadku daty dziennej jako jedyny potwierdza dane zawarte w $V$. N podaje jednak te informacje w inny sposób - nie w formie horoskopowego diagramu, tylko w postaci adnotacji umieszczonej przez kopistę pomiędzy tytułem a tekstem prognostyku. Co więcej, w tym właśnie przekazie $N$, a także w przechowywanym w Kórniku manuskrypcie $F b$, odnaleźć można również ważny parametr nieuwzględniony w $V$, a mianowicie „poli elevatio 51" (tak w $N$, w $F b$ w formie ,polus 51”), co oznacza, że obserwacje planet zostały przeprowadzone pod 51 stopniem szerokości geograficznej północnej. Fakt ten jest istotny, ponieważ niemal dokładnie taką szerokość przyjmowano w owym czasie dla Wrocławia, w którym wówczas rezydował Dudycz (i zgadza się ona z pewną

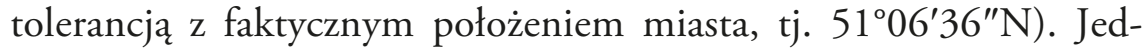
nocześnie należy podkreślić, że chociaż dokładna szerokość geograficzna Krakowa została ustalona dopiero w XVII w. przez Stanisława Pudłowskiego, jednak do tego momentu przyjmowano, że stolica

40 Por. J. D. North, op. cit., s. 2. 
Rzeczypospolitej znajduje się na 50 równoleżniku szerokości północnej ${ }^{41}$, a co nie odbiega od dokładnej, znanej obecnie szerokości geograficznej $\left(50^{\circ} 03^{\prime} 41^{\prime \prime} \mathrm{N}\right)$. Zważywszy na geograficzne kompetencje Retyka ${ }^{42}$ niemożliwe wydaje się, aby uznawał on za nieistotną różnicę jednego stopnia szerokości, ponieważ oznaczałoby to lekceważenie odległości rzędu $110 \mathrm{~km}$ (dla punktów znajdujących się na jednym południku, w tym wypadku jeszcze większej). To, że w kilku przekazach wspomniana jest szerokość Wrocławia, a brak w nich wzmianek na temat Krakowa, może pośrednio stanowić dowód sporządzenia przez Retyka horoskopu właśnie na zamówienie Dudycza lub na odpowiednie spreparowanie tekstu w jego kręgu.

5. W tekście pojawiają się elementy narracji pierwszoosobowej, rzucającej światło na sytuację komunikacyjną między astrologiem a zleceniodawcą (bez względu na to, kim ten ostatni był). Najwymowniejszym elementem jest tutaj kończące całość zdanie: „Gwiazdy nie pozwoliły mi dalej przepowiadać"; w różnych wariantach fraza ta pojawia się w kilku innych rękopisach, w tym w przekazach $\mathrm{Fb}, \mathrm{Ka}$ i $N$, które z pewnymi odstępstwami potwierdzają treść $V$.

6. Można wykazać oddziaływania $V$ na pozostałe zachowane przekazy, nigdy jednak na odwrót. Wszystkie elementy pojawiające się $\mathrm{w}$ innych rękopisach przepowiedni elekcyjnej, a niewystępujące w tekście $V$, są albo zniekształceniami kopistów, albo późniejszymi interpolacjami, których wyjaśnienia należy upatrywać w kontekście, w jakim powstawała konkretna kopia. Wśród przyczyn takiego stanu rzeczy należy wskazać tak różne i odległe od siebie czynniki jak: nieznajomość aparatu astrologicznego, fakt sporządzania kopii na podstawie innego, już uprzednio zepsutego i niekompletnego przekazu czy też chęć zmodyfikowania charakterystyk władców tak, aby bardziej przystawały do realiów, które zdążyły nastąpić od momentu powstania przepowiedni, dzięki czemu nadal mogła ona pozostać prawdopodobna. Nie wydaje się w każdym razie słuszne, aby którykolwiek z kopistów odpowiedzialnych za powstanie przekazów innych niż $V$ oraz wcześniejszych od niego manuskryptów $D d, F b, K a$ oraz $N$ miał dostęp do lepszego przekazu.

41 Takie położenie Krakowa podał m.in. Szymon Starowolski, por. idem, Polonia, Coloniae 1632, s. 41.

42 Por. jego niemiecki traktat geograficzno-chorograficzny: G. J. Rheticus, Chorographia Tewsch, w: Nicolaus Copernicus Gesamtausgabe, Bd. VIII/1: Receptio Copernicana: Texte zur Aufnahme der Copernicanischen Theorie, hrsg. von H. Nobis, A. M. Pastori, Berlin 2002, s. 75-88. 
7. Treść $V$ daje się zweryfikować i powiązać z czterema niepetnymi, ale blisko z nim spokrewnionymi przekazami $-D d, F b, K a$, $N$. Należy podkreślić, że rodzina tych pięciu manuskryptów nie jest jednorodna i że występują pomiędzy nimi różnice mające wpływ na możliwość rekonstrukcji archetypu. Obejmują one mianowicie takie aspekty horoskopu elekcyjnego jak występowanie diagramu horoskopowego (wyłącznie w $V$ ), zachowanie aparatu astrologicznego w tekście komentarza do horoskopu (niemal całkowicie został on pominięty w $D d$, przez co tekst jest znacznie krótszy od pozostałych świadków), wreszcie takie drobne odstępstwa jak pominięcia pojedynczych wyrazów, przestawienia kolejności wyrazów w obrębie mniejszych jednostek składniowych, mało istotne różnice w grafii, zastosowaniu niektórych przyimków oraz nieobecnością diagramu horoskopowego. W trakcie kolacjonowania pięciu przekazów pojawiły się pewne lokalne zgodności pomiędzy przekazami, jednak nie są one wystarczające do tego, aby wskazać dokładne zależności pomiędzy poszczególnymi przekazami. Nie zmienia to jednak faktu, że zasadniczo cztery przekazy o mniejszej wartości $(\mathrm{Dd}, \mathrm{Fb}, \mathrm{Ka}, \mathrm{Na})$ potwierdzają zawartość $V^{43}$.

5. Typy idealne przepowiedni elekcyjnej

W wypadku Vaticinium niemożliwe jest uszeregowanie przekazów według takiego modelu, który ukazywałby stopniową degenerację tekstu wraz z upływem kolejnych dekad i stuleci. Prawdą jest (z wyłączeniem $V$ ), że z im późniejszym przekazem mamy do czynienia, tym więcej znajduje się w nim zniekształceń w stosunku do $V$ traktowanego jako przekaz najbliższy - o ile nie identyczny $-\mathrm{z}$ archetypem, jednak wydaje się, że proces rozpadu tego tekstu, jego fragmentaryzacji i degeneracji, zaczął się relatywnie wcześnie i że na różnych etapach funkcjonowały równolegle zarówno uboższe, jak i pełniejsze jego warianty. Równolegle do procesu postępującej degeneracji tekstu Retyka przebiegał proces odwrotny, częściowo równoważący tę tendencję: pojawiły się bowiem warianty tekstu wykorzystujące ramową strukturę Vaticinium do wprowadzania dodatkowych treści. Tym samym relatywnie późne, bo dające się datować na drugą połowę czy wręcz samą końcówkę XVII stulecia i początek wieku XVIII manuskrypty przepowiedni niekoniecznie musiały mieć postać zbliżoną do wyliczeń i zestawień typu „diversi color” opisanych przez Andrzeja T.

43 Zob. aneks 1 dla editio variorum wszystkich pięciu przekazów. 
Klubińskiego ${ }^{44}$, ale miewały także rozbudowaną, osadzoną w aktualnym kontekście politycznym postać.

Niezależnie od tego, czy motorem zmian tekstu była niewiedza lub indyferencja względem pewnych warstw oryginalnego prognostyku, pragnienie realizacji własnego, propagandowo-politycznego zamysłu czy też najbardziej prozaiczny z powodów, a mianowicie brak dostępu do lepszej (bogatszej treściowo, również pod względem astrologicznym) kopii - to właśnie dzięki autorom wszystkich odpisów „przepowiednia" była tak długo żywym tekstem, gotowym do przyjmowania kolejnych elementów lub też ich wymiany - aż po okres konfederacji tarnogrodzkiej i panowanie Augusta II Mocnego.

Duże zróżnicowanie dostępnych świadectw sprawia, że nie jest możliwe zrekonstruowanie precyzyjnych zależności pomiędzy nimi. Przekazy te odbiegają od siebie pod tyloma względami, że trudno uznać je za bezpośrednio od siebie zależne - rekonstrukcja taka wymagałaby przyjęcia bardzo dużej ilości hipotetycznych tekstów pośredniczących pomiędzy poszczególnymi przekazami i de facto nie miałaby wielkiej wartości heurystycznej (podobnie jak ewentualne rozszerzenie bazy źródłowej o kolejne przykłady przekazów należące do tego samego typu). Zauważalne są jednak pewne regularności, zarówno na poziomie ogólnej struktury tekstu, jak i pewnych zespołów frazeologicznych. Umożliwiają one sformułowanie pewnych ogólniejszych wniosków na temat odmian tekstu, pomijających kwestie powiązań pomiędzy poszczególnymi egzemplarzami, oraz wskazanie na istnienie typów idealnych. W wypadku tych ostatnich możliwe jest już sformułowanie przekonujących - choć obarczonych pewnym ryzykiem błędu - wniosków na temat ich pochodzenia i oddziaływania na inne typy przekazu Vaticinium.

W ramach tej zróżnicowanej rodziny tekstów możliwe jest wskazanie następujących typów:

$(\alpha)$ archetyp: niezachowany, nie ma pewności, czyją ręką był sporządzony ${ }^{45}$;

44 A. T. Klubiński, op. cit.

45 Chociaż sam skłaniam się ku przyjęciu założenia, że autorem oryginalnego horoskopu był Retyk, należy również dopuścić taką możliwość, że horoskop elekcyjny był od samego początku astrologicznym falsyfikatem, narzędziem propagandy politycznej, w którym nazwiska astrologa użyto wyłącznie w celu uwiarygodnienia tekstu w oczach czytelników. Choć logicznie możliwa, hipoteza ta, podobnie zresztą jak sygnalizowane przeze mnie w innym miejscu przypuszczenie związane z datą 1 kwietnia, nie znajdują jednak poparcia w żadnych dokumentach. 
( $\beta$ ) odpisy archetypu: składają się z tytułu, wyliczenia losów poszczególnych władców z elementami astrologicznego komentarza po każdej charakterystyce. Tego rodzaju przekazów zaliczają się rękopisy $D d, F b, K a$ i $N$, a także najpełniejszy ze znanych rękopisów przekaz $V$;

$(\gamma)$ wariant skrócony: składa się z tytułu oraz „szkieletowej” wersji przepowiedni elekcyjnej, w której brakuje eksplanacji o charakterze astrologicznym, natomiast charakterystyki poszczególnych władców zostały znacznie zredukowane w stosunku do przekazów z rodziny $\beta$. Do tej rodziny rękopisów należą przekazy: $B, L a, L c, D a, D b, D c, M$ oraz $C$. To z tej rodziny przekazów wywodzą się najprawdopodobniej przedstawione przez A. T. Klubińskiego utwory typu „diversi color”;

$(\delta)$ wariant rozszerzony: oparty na strukturze rękopisów z rodziny $\gamma$, został jednak wykorzystany w zmieniającym się kontekście politycznym jako nośnik dla dodatkowych treści, obejmujących m.in. fakty związane z rzeczywistymi władcami oraz ich pozytywnie bądź negatywnie ocenianymi przez autora rękopisu osiągnięciami. Na tę rodzinę przekazów składają się rękopisy $F d, K b, R b, W a, W b$ oraz $W c$;

$(\varepsilon)$ wariant mieszany: w niektórych rękopisach wariant przekazu dającego się zakwalifikować jako należący do rodziny $\gamma$ został połączony z tekstem będącym częściową kopią $\beta$, przy czym - jak to miało miejsce w wypadku przekazu $L b$ - zdarzało się tak, że tylko „wersja skrócona” została przypisana Retykowi, drugą natomiast skopiowano jako anonimową przepowiednię. Analogiczny przypadek znaleźć można w następujących po sobie przekazach $F b$ i $F c$ - pierwszy jest niekompletną, podaną jako tekst anonimowy, wersją należącą do $\beta, \mathrm{w}$ drugim zaś (pokrewnym rodzinie $\delta$ ) nazwisko Retyka zostało zniekształcone („Bethaci” zamiast „Rhetici”). Innym przypadkiem jest rękopis $W d$, w którym wyliczenie charakterystyczne dla $\gamma$ lub $\delta$ przechodzi płynnie w narrację charakterystyczną dla $\beta$, która - co jest wyjątkiem - zawiera wprawdzie komentarz astrologiczny (nawet z wykorzystaniem astrologicznej symboliki), jednak treściowo i leksykalnie odbiega już od przekazów $D d, N$ oraz $V$, z których pomocą można wyznaczyć tekst Vaticinium możliwie najbliższy archetypowi;

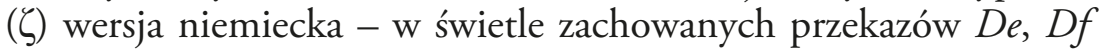
i $F a$ można uznać ją za próbę przekładu któregoś rękopisów zaliczających się do rodziny $\gamma$; jej powstanie należy wiązać najprawdopodobniej z ośrodkiem gdańskim, na co wskazuje zarówno silne powiązanie przekazów z innymi dokumentami związanymi z tym miastem, jak i brak innych świadków tego wariantu związanych z innymi ośrodkami; 
$(\eta)$ wersja polska - zachowana $\mathrm{w}$ trzech różnych przekazach $(R a$ z połowy XVII w. oraz $F e$ i $K c$ z przełomu XVII i XVIII stulecia), za każdym razem jednak, podobnie jak dwa rękopisy z rodziny $\zeta$, będąca pochodną „wersji skróconej” Vaticinium. Nie jest jasne, kiedy po raz pierwszy powstały pierwowzory tych tekstów ani jak duża pod względem ilości przekazów była ich tradycja. W świetle próby spolszczenia przez Jana Januszowskiego przepowiedni elekcyjnej w jego Wróż$k a c h^{46}$ można przypuszczać, że tekst ten mógł funkcjonować w jeszcze innych przekładach na język polski.

Takie uporządkowanie rodzin zachowanych przekazów pozwala na stworzenie co najmniej dwóch równie prawdopodobnych stemma codicum:

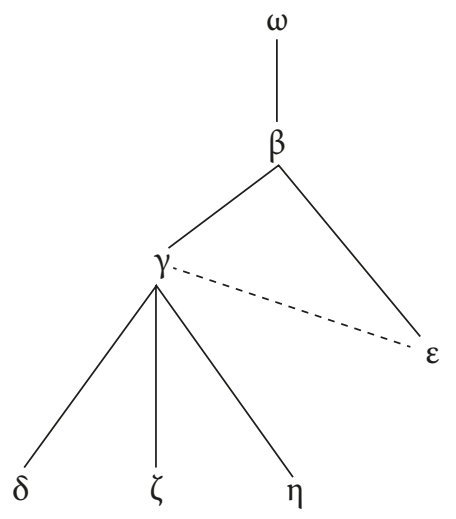

Ryc. 1

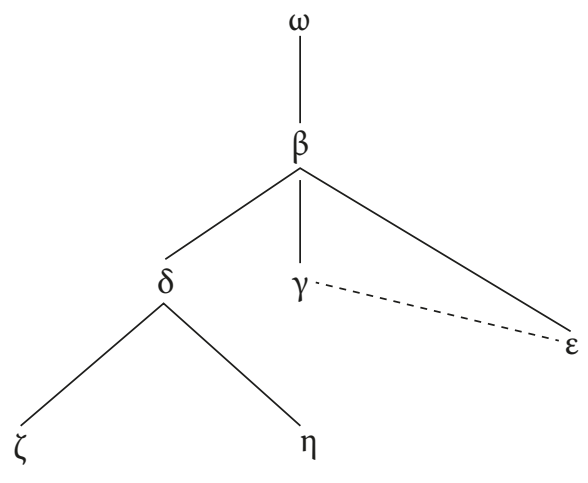

Ryc. 2

46 J. Januszowski, Wróżki, w: Staropolskie przepowiednie i mirabilia, s. 58. 
Pierwszy wariant (ryc. 1) zakłada równoległe rozwijanie się rodzin $\delta$, $\zeta$ oraz $\eta$, przy założeniu, że wszystkie wywodzą się z któregoś przekazu należącego do rodziny $\gamma$ oraz oddziaływanie tekstów do niej należących na formowanie się typu $\varepsilon$. (Jest to możliwe, jeśli uznamy, że, podobnie jak rodzina $\gamma$, wywodzi się on bezpośrednio z $\beta$ ). Drugi wariant (ryc. 2) opiera się z kolei na założeniu, że rodziny $\delta, \gamma$ oraz $\varepsilon$ wywodzą się z $\beta$, a przekazy $\mathrm{z}$ rodziny $\gamma$ oddziaływały na kształtowanie się $\varepsilon$. Niezależnie od tego, jakie rozstrzygnięcie zostanie przyjęte dla przekazów zaliczających się do typu $\delta$, dwie rodziny przekazów wernakularnych, czyli $\zeta$ oraz $\eta$, w obu interpretacjach wywodzą się bezpośrednio z rodziny $\gamma$. Oznacza to, że ich podstawę stanowi skrócona łacińska wersja Vaticinium, a świadczy o tym m.in. fakt, że przekłady niemieckie i polskie podążają dosyć wiernie pod względem formalnym i treściowym za tym właśnie typem.

Raz jeszcze należy podkreślić, iż w wyróżnieniu typów idealnych nie chodzi o utożsamienie ich z następującymi po sobie w czasie fazami. Taki obraz zamazywałby bowiem specyfikę dystrybucji poszczególnych rękopisów i mógłby prowadzić do mylnego przekonania, że wraz z pojawieniem się bardziej uproszczonej postaci przepowiedni z użycia wychodziła wersja bogatsza i bliższa archetypowi. Było wręcz odwrotnie: to, że w pewnym momencie pojawiła się w obiegu radykalnie skrócona wersja przepowiedni, nie wykluczało, że cały czas mogła być kopiowana któraś z jej dłuższych odmian. Istotną rolę odgrywała tutaj instancja kopisty lub zleceniodawcy kopii oraz środowiska, w jakim dany egzemplarz przepowiedni funkcjonował: ważne były tutaj zarówno indywidualne kompetencje piśmiennicze i językowe, charakter przekazu, na podstawie którego kopia była sporządzana, jak i cel powstania danego odpisu (począwszy od kolekcjonowania osobliwości aż po rozpowszechnianie propagandy politycznej) ${ }^{47}$.

47 Na temat obiegu kopii rękopiśmiennych zob. m.in.: Staropolska kultura rękopisu, red. H. Dziechcińska, Warszawa 1990; J. Partyka, Rękopisy dworu szlacheckiego doby staropolskiej, Warszawa 1995; A. Oszczęda, Z kroniki do sylwy. Wokót problemów rękopisu i druku w początkach XVII wieku. Część 1: Pieśn o zdobyciu Smoleńska Marcina Paszkowskiego. Uwagi o autorstwie i migracji tekstu, „Pamiętnik Literacki”, 102, 2011, z. 4, s. 175-180; eadem, Z kroniki do sylwy. Wokót problemów rękopisu i druku w początkach XVII wieku. Część 2: Wiersz Macieja Stryjkowskiego w lwowskim rękopisie Ossolineum, „Pamiętnik Literacki”, 104, 2013, z. 3, s. 231-248; M. Choptiany, „Dyjalog” Kasjana Sakowicza (1642) jako druk i rękopis. Siedemnastowieczne spory kalendarzowe i problem obiegu idei w kulturze staropolskiej, „Pamiętnik Literacki”, 107, 2017, w druku. 
6. Obieg rękopiśmienny przepowiedni Retyka Poza drogą z Krakowa do Wrocławia, jaką musiał odbyć pierwowzór przekazu $V$, niemożliwe jest naszkicowanie dokładnych trajektorii przestrzennych, wzdłuż których tekst Vaticinium był rozpowszechniany. Rekonstrukcja partykularnych powodów stojących za wpisaniem tekstu Vaticinium do kopiariusza, który ostatecznie drogą dziedziczenia i akcesji znalazł się w takich zbiorach jak kolekcja Ossolineum czy Biblioteki Czartoryskich, może stać się przedmiotem oddzielnych studiów przypadków. Mogą one dać interesujące poznawczo efekty nawet wówczas, gdy nie uda się ustalić tożsamości autorów poszczególnych kopii. Tekst przepowiedni, po wprowadzeniu do sylwy, znajdował się w kontekście innych wypisów - kopii listów i dokumentów, odpisów z tekstów drukowanych, formularzy korespondencji, luźnych zapisek, a nawet rysunków. Nie zawsze łatwo da się zidentyfikować proweniencję tego rodzaju kodeksu, a jeszcze trudniej jest czasami zrekonstruować powody warunkujące włączenie do rękopiśmiennej kolekcji konkretnego tekstu. Chociaż w zakresie niniejszego artykułu leży przede wszystkim ujęcie przekształceń formalnych, jakimi ulegał tekst Retyka pod piórami kolejnych kopistów, można zarysowany problem pokazać na dwóch przykładach, choć z zastrzeżeniem, że sformułowane przy tej okazji spostrzeżenia mają jedynie charakter wstępnych intuicji, które wymagają jeszcze dalszych badań źródłowych i weryfikacji.

Przykładem siedemnastowiecznego czytelnika, co do którego mamy pewność, że znał tekst przepowiedni, jest kasztelan biecki Jakub Michałowski (1612-1663) ${ }^{48}$. W jego bogatej spuściźnie rękopiśmiennej, rozdzielonej obecnie pomiędzy zbiory manuskryptów Biblioteki Narodowej w Warszawie oraz Biblioteki PAN i PAU w Krakowie, znaczną część tomów zajmują kopiariusze zawierające właśnie pokaźny zbiór wypisów wykonanych na podstawie druków. Do tej pory uwagę historyków przykuwała przede wszystkim działalność publiczna Michałowskiego, a z całego bogatego korpusu kilkunastu obszernych kodeksów częściowego opracowania edytorskiego doczekał się tylko jeden $\mathrm{z}$ nich, zawierający dokumenty powstałe za jego życia i w trakcie jego kariery politycznej ${ }^{49}$. Zwracano również uwagę na jego zainteresowania bibliofilskie, jednak nie pojawiło się do tej

48 A. Przyboś, Michatowski Jakub, PSB, 20, 1975, s. 652-654.

49 Zob. Jakuba Michatowskiego, wojskiego lubelskiego, a później kasztelana bieckiego księga pamiętnicza, wyd. A. Z. Helcel, Kraków 1864. 
pory żadne szerzej zakrojone studium pozwalające na bliższe poznanie jego lekturowych preferencji oraz strategii gromadzenia tekstów ${ }^{50}$. Wydaje się, że jednym z kluczy pozwalających zrozumieć strategię kompilowania i gromadzenia tekstów pochodzących z różnych tradycji i rejestrów kultury, tak dawnej, jak i Michałowskiemu współczesnej, jest zainteresowanie tekstami o charakterze profetycznym lub astrologicznym oraz fakt, że kasztelan biecki mógł dostrzegać w nich albo źródło objaśniające wydarzenia, których był świadkiem, albo narzędzie do kształtowania opinii szerszego kręgu odbiorców. Należy wyrazić przypuszczenie, iż do zbiorów swych świadomie włączał takie teksty, za pośrednictwem których mógł postrzegać współczesną sobie rzeczywistość polityczną i nadawać im dodatkowe, nierzadko sprzeczne z pierwotnymi intencjami autorów, sensy. To najprawdopodobniej z tego właśnie powodu $\mathrm{w}$ jego zasobach znalazł się m.in. odpis przekładu prognostyku padewskiego astrologa Andrei Argoliego wieszczącego rychły koniec świata ${ }^{51}$, kopia Przestrogi Jana Latosza z 1595 r., w której zawarta została wizja nadejścia potężnego władcy z dalekiej północy oraz panowania Antychrysta, zapewne bardzo pobudzająca wyobraźnię w latach szwedzkiej inwazji, zwłaszcza w oczach członka obozu Jana II Kazimierza ${ }^{52}$, wreszcie - jeden z prze-

50 Zob. M. Wichowa, Elementy biblioterapii w literaturze polskiej epok dawnych. Rekonesans historycznoliteracki, „Acta Universitatis Lodziensis. Folia Librorum”, 17, 2013, s. 56.

51 Por. BN, rkps 6634 III, k. 208rec.-215rec.: Straszna dziwnych skutków po wszytkim świecie methamorphosis przez Andrzeja Argola [...] spisana; wzmianka na k. 208rec. sugeruje, jakoby była to wierna kopia druku („Podana w druk ku dobru pospolitemu $\mathrm{z}$ wielkim tych wszytkich rzeczy uważeniem millesimo sexcentisimo quinq[uagesi]mo tertio), jednak nawet jeśli tak istotnie było, to żaden egzemplarz tej publikacji się nie zachował, zob. J. Kroczak, „Jeśli mię wieźdźba prawdziwa uwodzi..." Prognostyki i znaki cudowne w polskiej literaturze barokowej, Wrocław 2006, s. 142-144.

52 Zob. M. Choptiany, "Przestroga” Jana Latosza z 1595 roku. Prolegomena do edycji krytycznej na podstawie siedemnastowiecznego rękopisu z Biblioteki Narodowej w Warszawie, „Terminus”, 16, 2014, nr 2, s. 175-192; zagadnieniu reinterpretacji tekstu Latosza w latach potopu zostanie poświęcone odrębne studium. $\mathrm{Na}$ temat tekstów antyszwedzkich zob. m.in.: Z. Libiszowska, Antyszwedzka literatura propagandowa z czasów „potopu”, w: Polska w okresie drugiej wojny pótnocnej 1655-1660, t. 2: Rozprawy, Warszawa 1957, s. 481-527; A. Kersten, Geneza "Nowej Gigantomachii”, „Annales Universitatis Mariae Curie-Skłodowska”, Sectio F, 10, 1955, nr 1, s. 1-20; idem, Pierwszy opis obrony Jasnej Góry w roku 1655. Studia nad "Nowq Gigantomachia”" ks. Augustyna Kordeckiego, Warszawa 1958. 
kazów Vaticinium (kopia $R a$ ). Wytrawnemu politykowi i uczestnikowi elekcji, w trakcie których na tron polski wybrani zostali dwaj kolejni synowie Zygmunta III, horoskop mógł dostarczać inspiracji do dalszego działania na niwie polityki. Do tych tekstów należy jeszcze dodać szereg drobniejszych prognostykarsko-profetycznych zapisków obecnych na kartach niektórych kodeksów. Dokładniejsze poznanie pism samego Michałowskiego oraz pogłębiona analiza zależności treściowych pomiędzy poszczególnymi wypisami, zamkniętymi w materialnej, zindywidualizowanej intertekstualnej sieci, może przynieść dalsze ustalenia na temat roli, jaką kasztelan biecki przypisywał tego rodzaju utworom i jak z nich korzystał.

Drugi przykład ilustruje $\mathrm{z}$ dużym prawdopodobieństwem typ recepcji przepowiedni Retyka, który przebiega na styku dwóch płaszczyzn: indywidualnej, związanej z preferencjami i celami konkretnych kopistów, oraz środowiskowej, obejmującej szersze tendencje i zespół przekonań podzielanych przez członków danej warstwy społecznej czy też mieszkańców jednego miejsca. Wydaje się, że takie właśnie specyficzne środowisko odbiorców Retykowego tekstu stanowili gdańscy mieszczanie, a być może także szerzej - mieszkańcy Prus Królewskich. $\mathrm{Na} 33$ zidentyfikowanych (w tym 28 zachowanych) przekazów różnych wariantów przepowiedni elekcyjnej aż 11 manuskryptów (w tym 7 zachowanych) charakteryzuje się niepodważalną proweniencją gdańską ${ }^{53}$. Spośród 7 dostępnych dziś "gdańskich” rękopisów Retykowej przepowiedni aż 6 do dnia dzisiejszego znajduje się w zbiorach nad Motławą, co stanowi rezultat prowadzonej w ubiegłych stuleciach przez bibliotekę gdańskiej Rady polityki donacji i akcesji. W przeciwieństwie do kolekcji będących późniejszymi, bo osiemnastolub dziewiętnastowiecznymi fundacjami zawierającymi zbiory o bardzo zróżnicowanej, m.in. geograficznie, strukturze proweniencyjnej, można mieć pewność co do tego, że gdańskie odpisy przepowiedni powstały właśnie tam. Świadczą o tym zarówno charakterystyki proweniencyjne egzemplarzy, tak zachowanych, jak i zaginionych, stanowiące dowód związku tych manuskryptów z dziejami miasta, dlatego w naturalny sposób trafiły do dawnej Biblioteki Miejskiej, obecnej Biblioteki Gdańskiej PAN. Dotyczy to zarówno przekazów takich jak $D b, D g, D j$ oraz $F a$, powiązanych bezpośrednio z postaciami

53 Są to odpowiednio: w języku łacińskim - 4 zachowane $(D a, D b, D c, D d)$ i 1 zaginiony $(D h)$, w języku niemieckim - 3 zachowane $(D e, D f, F a)$ i 3 utracone $(D g, D i, D j)$. 
osiemnastowiecznych gdańskich uczonych i kolekcjonerów (odpowiednio: Daniela Gralatha, Walentego Schlieffa, Andreasa Schotta i Bartolomeusa Wartzmanna), jak również pozostałych przekazów i kodeksów, których część one stanowią. W wypadku innych kodeksów zawierających tekst przepowiedni nie został on nigdy osadzony w tak wyrazistym kontekście wewnętrznych i zewnętrznych spraw Gdańska i - szerzej - Prus Królewskich. W związku z tym wydaje się, że to właśnie port nad Motławą można uznać za miejsce, gdzie prawdopodobnie dokonany został przekład Vaticinium na język niemiecki. Nie jest w każdym razie znany przekaz w tym języku zachowany w kodeksie niemającym związku z tym miastem.

Za takim odczytaniem przemawia również fakt, iż Retykowe Vaticinium wpisane zostało nie tylko w kontekst konkretnej lokalnej polityki poprzez włączanie niektórych przekazów (jak np. w wypadku $D a$ ) w ciąg kopii dokumentów związanych z relacjami między Rzecząpospolitą i Prusami Królewskimi, ale horoskop interpretowano także symbolicznie. Przykładem tej drugiej tendencji mogą być dwa gdańskie łacińskie przekazy Retykowej przepowiedni, $D a$ oraz $D c$, po których następują teksty Jana Dantyszka, znane jako Vaticinium oraz Jonas Propheta ${ }^{54}$. Również w wypadku kodeksu zawierającego przekaz $D e$, bardzo starannie wykonanego i mającego charakter kompendium historycznego na temat dziejów miasta, w bezpośrednim sąsiedztwie tekstu Vaticinium oder Weissagung można odnaleźć niemiecki przekaz Dantyszkowej poetyckiej przepowiedni ${ }^{55}$. Elementy te dowodza, że przepowiednia elekcyjna została przez niektórych użytkowników dosyć mocno powiązana z lokalną profetyczno-literacką tradycją zainicjowaną przez Dantyszka i stworzoną przezeń wizją losów Gdańska i Polski, w równym stopniu opartą na popularnej topice apokaliptycznej, co na lokalnym kontekście politycznym, wyznaniowym i społecznym $^{56}$. Z całego spektrum przekazów przepowiedni autora Pochwaty

54 Zob. odpowiednio BG, Ms. 694, k. 202rec. i n. oraz Ms. 821, k. 2rec.-2ver.

55 Por. BG, Ms. 907, s. 70.

$56 \mathrm{Na}$ ten temat zob.: Z. Nowak, Antyreformacyjna elegia Dantyszka o zagtadzie Gdańska, OiRwP, 16, 1971, s. 3-35; A. Skolimowska, Vaticinium ruiturae Poloniae. Was Dantiscus Foretelling the Downfall of Poland?, w: Corpus Epistularum Ioannis Dantisci, p. 5: Respublica Litteraria in Action, vol. 3: New Sources, red. K. Tomaszuk, Warsaw 2016, s. 99-113. Na temat kultury umysłowej Gdańska i Prus Królewskich w okresie nowożytnym zob. m.in. B. Nadolski, Ze studiów nad życiem literackim i kultura umystowa na Pomorzu w XVI i XVII wieku, Wrocław-Warszawa-Kraków 1969. 
Prus $^{57}$ egzemplarze związane z Gdańskiem tworzą najmocniejszą i najłatwiejszą do udokumentowania konstelację i to pomimo faktu, że różnią się między sobą pod względem formy i objętości.

Oba przykłady - Michałowskiego i gdański - dowodzą dużej pojemności znaczeniowej tekstu przepowiedni, ułatwiającej łączenie jej z innymi utworami (zarówno literackimi, jak i dokumentami) oraz z lokalnym i aktualnym kontekstem politycznym. Jedną z podstawowych praktyk związanych z tekstem było „sprawdzanie” przepowiedni - weryfikacja charakterystyk ex post, czego ślady odnaleźć można na marginesach wielu przekazów. Jednak oprócz tego powszechnie stosowanego sposobu jej odczytywania użytkownicy wplatali ów tekst w bardziej złożone konstelacje, które dzisiaj z perspektywy kilku stuleci stanowią niezwykle cenne źródło do badania różnych aspektów nowożytnej mentalności - stosunku do sfery nadprzyrodzonej, poglądów politycznych, przekonań na temat przyszłości itp. Przepowiednia Retyka - a raczej to, co z nią robiono - może stanowić jeden z probierzy $\mathrm{w}$ tego rodzaju badaniach, dopełniających niniejsze ustalenia źródłoznawcze i edytorskie.

\section{P odsumowanie}

Powyższe tezy nie rozstrzygają wielu kwestii. Między innymi nie jest do końca jasne, jak doszło do tego, że warianty przepowiedni wyrastające z tego samego pnia, tj. „archetypicznego” horoskopu Retyka, zaczęły funkcjonować do tego stopnia niezależnie, że przekazy należące do dwóch oddzielnych gałęzi tradycji odnaleźć można na kartach jednego kodeksu, czego przykładem para krakowskich przekazów (Ka i $K b)$, które rozdziela kilkaset stron, oraz przekazów $F b$ i $F c$, które następują bezpośrednio po sobie w ramach jednej sylwy. Wydaje się, że dla twórców tych sylw i kopiariuszy teksty te musiały sprawiać wrażenie niezależnych do siebie całości (choć zapewne dopowiadających wzajemnie pewne treści) i że proces rozdzielenia się tych dwóch odmian - jednej pozostającej w związku z pierwotnym horoskopem i drugiej bliższej popularnej, wolnej od astrologicznego aparatu, przepowiedni - nastąpił przed sporządzeniem tych trzech par rękopisów, na co wskazują choćby, raz jeszcze, zniekształcenia nazwiska Retyka, mające swoje źródło w innych, służących za podstawy, wadliwych kopiach.

57 Zob. J. J. Retyk, Relacja pierwsza, s. 138-147; por. też I. Lewandowski, Jerzy Joachim Retyk i jego „Pochwata Prus”, „Rocznik Gdański”, 32, 1972, z. 2, s. 73-94. 
Nie udało się również rozstrzygnąć, w którym dokładnie momencie doszło do wyłonienia się rodziny tekstów „diversi color” - jakkolwiek ma ona związek z horoskopem Retyka, to stoję na stanowisku, że stanowi ona oddzielny zespół tekstów, powstałych w równym stopniu pod wpływem Retykowego prognostyku, jak i innych tekstów (tekstowych wzorców) o charakterze profetyczno-politycznym - w tym wypadku kluczową rolę odegrało również rozpowszechnione w nowożytnych sylwach proroctwo św. Malachiasza, zawierające zestawienie papieży wraz z ich krótkimi charakterystykami. Jest wysoce prawdopodobne, że do tego krzyżowego połączenia się dwóch tradycji tekstualnych doszło stosunkowo wcześnie i że przez dosyć długi czas zarówno stopniowo degenerujące się przekazy oryginalnego Vaticinium, jak i wytwory nowej tradycji funkcjonowały równolegle $\mathrm{w}$ odpisach, kopiowane zapewne z tych samych powodów, ale niekoniecznie ze świadomością ich sięgającego wiele dekad wstecz źródłowego pokrewieństwa.

Niemożność jednoznacznego rozstrzygnięcia tych zagadnień, a także rozwiązania problemu intencji niektórych kopistów odpowiedzialnych za sporządzenie znacznej ilości odpisów Vaticinium w takim czy innym wariancie, nie mogą przesłaniać jednak faktu najważniejszego: horoskop elekcyjny Retyka, nawet w wersji okrojonej i pozbawionej już aparatu astrologicznego, mającej charakter popularnego tekstu, a nie profesjonalnego prognostyku, odegrał ważną rolę w systemie informacji i propagandy politycznej w okresie pomiędzy śmiercią Zygmunta Augusta a (co najmniej) panowaniem pierwszego Wettyna na polskim tronie. Żaden inny tekst o proweniencji astrologicznej nie przedarł się z taką siłą do szlacheckich i mieszczańskich kopiariuszy, i nawet jeśli trafiał przez to do bardzo zróżnicowanych społecznie, politycznie i wyznaniowo lokalnych wspólnot interpretacyjnych, to wszystkie te przypadki łączą się ze sobą zainteresowaniem dalszym rozwojem spraw politycznych w Rzeczypospolitej i umiejscawianiem tych tekstów w większych zbiorach obejmujących teksty literackie, pisma polityczne, mowy i listy. W związku z tym jest prawdopodobne, że - przynajmniej w niektórych przypadkach - tekstu Retykowego prognostyku nie kopiowano wyłącznie mechanicznie jako wartą zachowania osobliwość, ale że oddziaływał on dalej w trakcie kolejnych lektur owocujących sporządzaniem innych utworów, które miały zaistnieć w systemie napięć pomiędzy kolejnymi elekcyjnymi władcami a obozem szlacheckim. 
Aneks 1

Vaticinium Jerzego Joachima Retyka rekonstrukcja wersji podstawowej

Poniżej podaję tekst przepowiedni elekcyjnej Retyka w formie editio variorum obejmującej zidentyfikowane przekazy najpełniejszej wersji Vaticinium. Utwór po raz pierwszy został wydany z rękopisu $V$ przez K. H. Burmeistra, jednak z uwagi na fakt, iż mamy do czynienia z wiarygodnym, lecz późnym przekazem, wskazane jest również porównanie go z innymi zachowanymi świadkami archetypu. Tekst edycji podąża tutaj zasadniczo za $V$, jednak wprowadzone zostały m.in. korekty interpunkcji i postanowiono uwzględnić również pewne drobne elementy zachowane w przekazach $D d$ i $N$. W tekście głównym zachowano notację symboliczną dla nazw ciał niebieskich i zjawisk astrologicznych takich jak kwadrat czy koniunkcja, zakładając, że taka mogła być pierwotna wersja tekstu (napisanego przez świadomego swojego rzemiosła astrologa) wyrastająca $z$ horoskopowego diagramu. Należy jednocześnie podkreślić, iż ze wszystkich trzech wykorzystanych tutaj przekazów $G d$ jest wariantem najuboższym i pomija np. całkowicie elementy komentarza astrologicznego - można go zatem interpretować jako jedną z form przejściowych na drodze, jaką kompletny tekst Vaticinium odbył, osiągając ostatecznie postać krótkich, jednolub dwuzdaniowych wyliczeń. Towarzysząca edycji ryc. 3 podana zostaje za przekazem $V$ i w nieznacznie skorygowanej w stosunku do diagramu, który można odnaleźć w edycji Burmeistra, formie.

Źródła:

Dd Gdańsk, Biblioteka Gdańska PAN, Ms. Uph. fol. 26, s. 243

Fb Kórnik, Biblioteka Kórnicka PAN, rkps 341, k. 185rec.-ver.

Ka Kraków, Biblioteka Jagiellońska, rkps 118, s. 235-237

$N$ Milano, Biblioteca Ambrosiana, D 208 inf., k. 170rec.-171 rec.

$V$ Wrocław, Biblioteka Uniwersytecka, rkps Akc. 1949/594, k. 56ver.-57ver.

Oznaczenia i skróty:

[ ] rozwinięcie skrótu

(?) lekcja niepewna

del. delevit (tekst wykreślony)

ins. inseruit (tekst wprowadzony później)

om. omisit (tekst pominięty)

sic tak $\mathrm{w}$ rękopisie 
Iudicium $^{a} \mathrm{D}$ [omi]ni Georgii Ioachimi Rhaetici, medici et astronomi peritissimi, ${ }^{\text {b }}$ de successoribus in regno Poloniae post obitum regis Sigismundi $\mathrm{II}^{\mathrm{c}}$ anno $1571^{\mathrm{d}}$

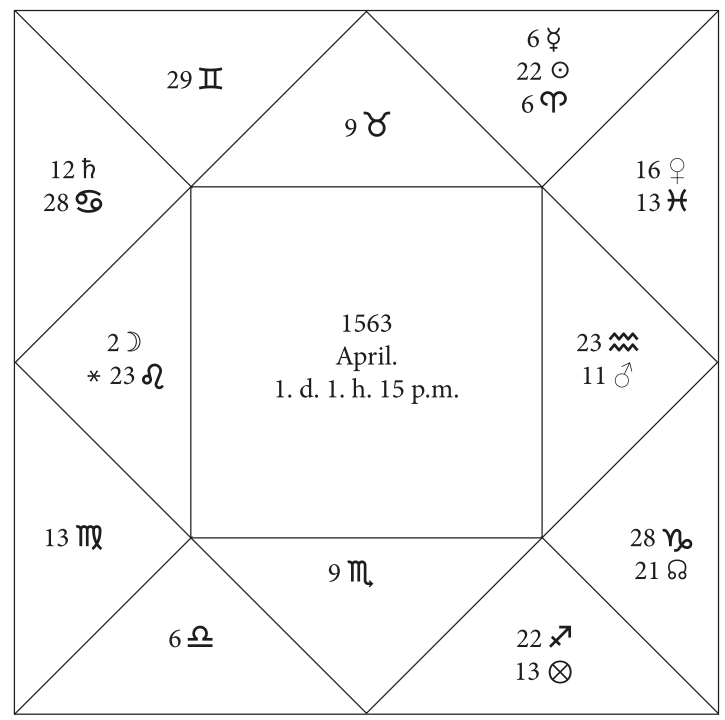

Ryc. $3^{\text {e }}$

Anno MDLXIII, 1. die Aprilis, hora 1., minut[orum] 15 post meridiem, poli elevatio $51 .^{\mathrm{f}}$

Quaestio utrum regimen istius principis Sigismundi Augusti est duraturum?g Item $^{\mathrm{h}}$ an sub alio melior gubernatio foret? ${ }^{\text {i }}$

a Iudicium] Responsum Dd Prognosticon Ka om. FbN.

b Domini ... peritissimi] Joachimi Mathematici doctissimi Dd om. FbKa Reticus Medicus et Astrologus Cracoviensis $N$.

c de ... Sigismundi II] ad quaesitum Sigismundi Augusti Regis Poloniae Dd Regum Polonorum quorundam $\mathrm{Ka}$ om. $\mathrm{FbN}$.

d anno 1571] om. DdFbKaN del. V.

e Ryc. 3] om. DdFbKaN.

${ }^{\mathrm{f}}$ Anno ... 51] om. DdKaV Anno Domini MDLXIII Aprilis prima die, hora prima, minuta 15 post meridiem, polus $51 \mathrm{Fb}$.

g Quaestio ... duraturum?] Quaestio utrum regnum istius principis duraturum $F b$ om. $\mathrm{Ka}$ Quaestio utrum istius Principis est diu duraturum Imperium $N$.

${ }^{\mathrm{h}}$ Item] et $\mathrm{Dd}$ om. KaN.

i an ... foret] an sub alio gubernatio melior feliciorq[ue] duratura $D d$ an sub alio melior foret gubernatio $\mathrm{Fb} \mathrm{om}$. Ka an sub alio melior futura gubernatio $N$. 


\section{Designatio ${ }^{a}$}

Quoniam signa ascendentia anguli ${ }^{\mathrm{b}}$ orientis $\mathrm{et}^{\mathrm{c}}$ medii coeli

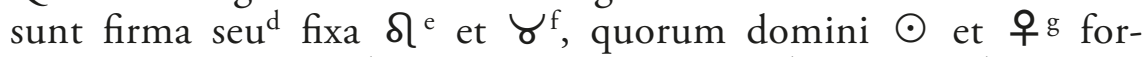
tes in exaltationibus ${ }^{\mathrm{h}}$ suis sunt $\mathrm{t}^{\mathrm{ij}}$. Nempe in ${ }^{\mathrm{k}} \gamma$ et $00^{\mathrm{l}}$ manifeste $^{\mathrm{m}}$ denotant $^{\mathrm{n}}$, quod huius regis dominatio ${ }^{\mathrm{o}}$ non tantum diuturna existet; sed $\mathrm{p}^{\mathrm{p}}$ etiam ${ }^{\mathrm{q}}$ in dies celebrior ${ }^{\mathrm{r}}$ futura est, quae nec bello nec seditione ulla, si acciderit ${ }^{\mathrm{s}}$, ei $^{\mathrm{t}}$ vivo auferri possit ${ }^{\mathrm{u}}$. Id cor $\Omega^{\mathrm{v}}$ stella toto orbe fulgentissima in linea orientis denotat ${ }^{\mathrm{w}}$. Et $\zeta^{\mathrm{x}}$ tribus $^{y}$ gradibus ante centrum domus regiae in sua facie constitutus $\mathrm{a}^{\mathrm{z}}$ 우 ${ }^{\mathrm{aa}}$ domina sui ${ }^{\mathrm{bb}}$ signi receptus ${ }^{\mathrm{cc}}$ confirmat $^{\text {ddeeff }}$.

${ }^{a}$ I. Designatio] om. DdFbKaV.

b anguli] om. $N$.

c et] ex $K a$.

d seu] sive $K a$.

e 8$]$ ] Leo $K a$ Mars sic $N$.

f ૪] Taurus Ka Mercurius sic $N$.

g $\odot$ et 우] Sol et Venus KaN.

h exaltationibus] exhalationibus sic $N$.

i sunt] om. DdNV.

j Quoniam ... sunt] om. Fb.

${ }^{\mathrm{k}}$ Nempe in] om. DdFbNV.

${ }^{1} \checkmark$ et 00 ] om. $\mathrm{Fb}$ Ariete et Piscibus $\mathrm{Ka}$ Chrysi(?) et Pisces sic $N$.

m manifeste] manifesti $N$.

${ }^{\mathrm{n}}$ indicant] indicant stellae $\mathrm{Fb}$ denotant $\mathrm{Ka}$.

o dominatio] gubernatio $F b$.

P sed] verum $K a$.

q etiam] et in $F b$.

${ }^{r}$ celebrior] celebratior $N$.

s si acciderit] etiamsi acciderit $\mathrm{Ka}$ ea accidet $N$.

t ei] a $N$.

" possit] poterit $\mathrm{Ka}$.

v §] Leonis KaN.

${ }^{w}$ orientis denotat] orientis indicat denotat $N$.

$x \quad$ ఈ ] Mercurius $K a$.

y tribus] quatuor $K a$.

z a] om. N.

aa ㅇ] Veneri $K a$ Venus $N$.

bb sui] om. Ka.

${ }^{c c}$ receptus] aspectans $\mathrm{Ka}$.

dd confirmat] hoc ipsum confirmat $K a$.

ee Id ... confirmat] om. Fb.

${ }^{\text {ff }}$ Quoniam ... confirmat] om. Dd. 
II. ${ }^{\mathrm{a}}$

Ceterum $^{\mathrm{b}}$ cum e vivis discesserit ${ }^{\mathrm{c}}$ : Clementissimus princeps iustitia et pietate insignis in locum eius succedet ${ }^{\mathrm{d}}$, sed ${ }^{\mathrm{e}}$ brevissimo temporis spatio $^{f}$ praeerit $^{g}$. Ita, ut cum regnare coepit ${ }^{\mathrm{h}}$ suamque probitatem et prudentiam $^{\mathrm{i}}$ declarare voluerit ${ }^{\mathrm{j}}$, vel fato functus intercludetur vel alia ratione desistet ${ }^{\mathrm{k}}$. Hoc habetur ex $2^{1}$ in succedente medio coeli fineque signi collocato ${ }^{\mathrm{m}}{ }^{\mathrm{n}}$

III. $^{\circ}$

Porro sublato inquissima fatorum lege futuro ${ }^{\mathrm{P}}, \operatorname{tam}^{\mathrm{q}}$ praestantissimo $^{\mathrm{r}}$ principe, occupabit regnum ${ }^{\text {st }}$ sceleratissimus quidam senex ${ }^{\mathrm{u}}$, severus et avarus, viliv familia oriundus ${ }^{\mathrm{w}}$, cuius dominatio tristis, exitialis et funesta huic regno futura est ${ }^{\mathrm{x}}$. Adiungetque ${ }^{\mathrm{y}} \operatorname{sibi}^{\mathrm{z}} \operatorname{administratione}^{\mathrm{aa}}$

${ }^{a}$ II.] om. $F b K a$ I. $V$.

b Ceterum] om. Dd Caeterum FbN.

c Cum ... discesserit] Sigismundus decesserit $D d$ cum e vivis decesserit $F b$.

d succedet] qui succedet $D d$.

e sed] om. Dd.

${ }^{\mathrm{f}}$ brevissimo ... spatio] brevi temporis spatio $\mathrm{Dd}$ levissimo temporis spatio $\mathrm{Fb}$ brevissimo spatio temporis $K a N$.

${ }^{g}$ praeerit] in regno erit $D d K a$.

h coepit] coeperit Dd om. Fb caeperit KaN.

${ }^{i}$ probitatem et prudentiam] prudentiam et propositum $D d$ probitatem ac prudentiam $F b$ prudentiam ac probitatem $N$.

j voluerit] noluerut $D d$ caeperit $F b$ om. $N$.

${ }^{k}$ desistet] regnare cessabit $D d$ regnare desistet $K a$.

1 2[] Jove KaN.

m collocato] om. Ka collocati $N$.

${ }^{\mathrm{n}}$ Hoc ... collocato] om. DdFb.

- III.] om. DdFbKa II. $V$.

P futuro] om. FbKaV.

q tam] om. $N$.

${ }^{\mathrm{r}}$ praestantissimo] potentissime $N$.

s regnum] om. $F b$.

t Porro ... regnum] Sublato deinde hoc succedet in Regnum $D d$.

u sceleratissimus ... senex] quidam senex sceleratissimus $\mathrm{Fb}$ quidam senex $\mathrm{Ka}$.

v vili] nihili $N$.

w oriundus] oriendus $D d$.

x cuius ... est] om. $D d$.

y Adiungetque] III. Adiungetque $V$.

z sibi] in $N$.

aa administratione] in administrationem $D d F b K a$. 
socium omnino $^{\mathrm{a}}$ sibi similem ${ }^{\mathrm{b}}$, sed magis ferum et immanem ${ }^{\mathrm{c}}$. Hoc minatur $h$ cum $\checkmark$ in $\sigma^{\mathrm{d}}$ suo detrimento existens, et ${ }^{\mathrm{e}} 2 \Psi^{\mathrm{mf}}$ secundum $^{\mathrm{g}}$ signorum seriem sequens ${ }^{\mathrm{h}}{ }^{\mathrm{i}}$

IV.$^{\mathrm{j}}$

Post hos $^{\mathrm{k}}$ eligetur ${ }^{\mathrm{l}}$ ex indigenis popularibus equestri ordine ${ }^{\mathrm{m}}$ natus novus iuvenis, princeps callidus ${ }^{\mathrm{n}}$ et ambitiosus, rei militari ${ }^{\mathrm{o}}$ peritus. Sed ${ }^{\mathrm{p}}$ qui tamen ${ }^{\mathrm{q}}$ in bello vel ${ }^{\mathrm{r}}$ gladio peribit $^{\mathrm{s}}$. Eius $^{\mathrm{t}}$ gubernatio regni ${ }^{\mathrm{u}}$ mediocris erit ${ }^{\mathrm{v}}$. Hoc significat $D$ in initio $\delta^{\mathrm{w}}$, praemissos subsequentes $^{\mathrm{x}}$ planetos in $\square$ 하 applicans $^{\mathrm{z}}$ o a a $\delta^{\mathrm{tbb}}$.c $^{\mathrm{c}}$

a socium omniono] om. $N$.

b sibi similem] similem sibi $D d N$.

c immanem] inhumanum $N$.

d $h$ cum $\checkmark$ in 6$]$ Saturnus cum Cauda Draconis coniunctus in Cancro $\mathrm{Ka}$ Saturnus cum Ariete in Cancro $N$.

e et] om. $K a$.

f 2 ] $]$ om. $K a$ Jupiter $N$.

g secundum] om. $K a$.

h signorum seriem sequens] om. Ka signam successione sequetur $N$.

i Hoc ... sequens] Vel etiam protunc administrans Reipublicam sine rege, tristis exitialis et funesta huic regno futura est $D d o m$. Fb.

j IV.] om. FbKa IIII. $N$.

k Post hos] Post hunc vel ea tempestate Dd Post hos autem Fb Post hunc Ka Post aut $N$.

1 eligetur] om. $\mathrm{Fb}$.

m ex ... ordine] ex indigenis equestris ordinis $D d K a$.

${ }^{n}$ callidus] calidus $D d$.

o militari] militaris $D d$.

p Sed] om. $F b$.

q tamen] tum $D d$.

${ }^{r}$ vel] a $D d$.

$s$ gladio peribit] gladio peribit vel quacunque alia morte succumbet $K a$.

${ }^{t}$ Eius] Cuius $D d K a$ Eiusque $F b$.

u regni] om. $K a$ regno $N$.

v peribit] peribit vel quacunque alia morte succumbet $D d$.

w $\mathcal{D}$ in initio $\delta$ ] Luna in initio Leonis $K a N$.

x subsequentes] subsequens $\mathrm{KaV}$.

$\mathrm{y}$ in $\square$; ] in quadrat Mercurii Ka om. $N$.

z Applicans]] om. Ka.

aa 8] et opposito $\mathrm{Ka} \mathrm{om.} N$.

bb う]] Martis Ka Marti $N$.

сc Hoc ... ठ] om. DdFb. 
$\mathrm{V}^{\mathrm{a}}$

Cum autem huius regis gubernatio ${ }^{b}$ defierit $^{c}$, clarissimus quidam princeps ex illustrissima familia oriundus ${ }^{\mathrm{d}}$, potens et ${ }^{\mathrm{e}}$ magnanimus $\mathrm{f}^{\mathrm{f}}$, potentia $^{g}$ potius sua ${ }^{\mathrm{h}}$ quam per electionem hoc $^{\mathrm{i}}$ regnum $^{\mathrm{j}}$ occupans feliciter et ${ }^{\mathrm{k}}$ diutissime $^{\mathrm{l}}$ nobis praeerit ${ }^{\mathrm{m}}$, qui et in pace iustitia et in bello $^{\mathrm{n}}$ fortitudine ${ }^{\mathrm{o}}$, cum maximo huius regni commodo imperabit, mirum in modum puniet malos et praemio $^{\mathrm{p}}$ afficiet bonos. Victor $\mathrm{ac}^{\mathrm{q}}$ triumphator regni, fines ${ }^{\mathrm{r}}$ gloriamque nominis sui, longe lateque extendit ${ }^{\mathrm{s}}$, supplicibus hostibus parcet, adversantes ${ }^{\mathrm{t}}$ opprimet $\mathrm{ac}^{\mathrm{u}}$ proteret, adeo ut vix ${ }^{\mathrm{v}}$ melior $\mathrm{et}^{\mathrm{w}}$ fortunatior optari possit. Ex cuius etiam $^{\mathrm{x}}$ familia diu apud nos reges erunt ${ }^{\mathrm{y}}$. Huius fert ${ }^{\mathrm{x}}$ effigiem cor $\delta^{\text {aa }}$ in centro orientis, Pisces, Jupiter, Sol ${ }^{\text {bb }}$ faelicissime exoriens ${ }^{\text {ccdd }}$.ee

${ }^{a}$ V.] om. DdFbKa.

${ }^{\mathrm{b}}$ huius ... gubernatio] gubernatio huius regis $D d$.

c defierit] desierit $N$.

d oriundus] om. FbNV.

e et] ac $F b$.

${ }^{\mathrm{f}}$ magnanimus] magnonimus $D d$.

g potentia] potentiam $D d$.

h sua] om. Dd.

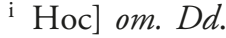

' hoc regnum] om. $N$.

k feliciter et] feliciter ac $F b$ faelicissime ac $N$.

${ }^{1}$ diutissime] diuturnissime $F b$.

${ }^{m}$ praeerit] om. Ka.

${ }^{n}$ et in pace ... bello] qui et pace et iustitia in bello $F b$.

o qui ... fortitudine] om. DdKa.

P praemio] praemiis $F b N$.

q ac] et $F b K a N$.

${ }^{r}$ fines] finies $N$.

s extendit] propagabit $D d K a$ extendet $F b N$.

t adversantes] adversarios $N$.

u ac] et $D d F b$.

v vix] nullus $D d$ Rex $K a$.

w et] ac $F b N$.

x cuius etiam] eiusque $D d$ cuius et $F b$ cuius $K a N$.

${ }^{y}$ reges erunt] regnabunt $D d$ regnabunt reges $K a$.

${ }^{z}$ fert] habet $K a$ fere $N$.

aa $\delta]$ Leonis $K a N$.

bb Pisces, Jupiter, Sol] in sextili Iovis et trino Solis $\mathrm{Ka}$.

${ }^{c c}$ exoriens] exurgens $K a$.

dd Pisces ... exoriens] om. $V$.

ee Huius ... exoriens] om. $D d$. 
Sed cum omnia mortalia interitui obnoxia sint $\mathrm{t}^{\mathrm{a}}$, et ${ }^{\mathrm{b}}$ hic princeps vel potius haeres ${ }^{c}$, indignus qui moriatur ${ }^{\mathrm{d}}$, cum diutissime regnaverit, fato fungeture. ${ }^{\mathrm{e}}$

VI.g

Cuius $^{\mathrm{h}}$ in locum succedet etiam ${ }^{\mathrm{i}}$ bonus, benignus et iuvenis princeps $^{j}$, sed qui electus, licet ${ }^{\mathrm{k}}$, regia potestate et $^{\mathrm{l}}$ nomine imperabit $^{\mathrm{m}}$ tamen nescio quo casu, numquam ${ }^{\mathrm{n}}$ dum vixerit, coronabitur ${ }^{\circ}$. Hunc mihi $\mathrm{i}^{\mathrm{p}}$ indicat $\delta$ in $\boldsymbol{h}^{\mathrm{q}}$ post regulum proximum ${ }^{\mathrm{r}} .^{\mathrm{s}}$

VII. ${ }^{\mathrm{t}}$

Deinde $^{\mathrm{u}}$ ad quendam militarem virum ${ }^{\mathrm{v}}$ regnum devolvetur, qui crudeliter praeerit ${ }^{\mathrm{w}}$. Nam ${ }^{\mathrm{x}}$ homo severus, ferox ${ }^{\mathrm{y}}$, agrestis ${ }^{\mathrm{z}}$ et inexorabilis

a sint] om. Ka.

b et] om. Dd.

c potius haeres] potius heros $D d$ potuis heros $N$.

d indignus qui moriatur] (indignum est quod moriatur) $N$.

e fungetur] fungit $K a$.

f Huius ... fungetur] om. $F b$.

g VI.] om. DdFbKa.

h Cuius] Huius $D d$.

i etiam] et iam $D d o m$. FbN.

j bonus ... princeps] bonus etiam benignus, iuvenis princeps $F b$ bonus et benignus iuvenis et Princeps $N$.

k electus, licet] licet electus $N$.

l et] ac $N$.

m imperabit] imperabile $V$.

n numquam] unquam $F b$.

o nescio ... coronabitur] nescio dio vixerit quam ob. causam nunquam coronabitur $D d$.

p mihi] om. $N$.

q $\Omega$ in $\bullet$ ] Caput Draconis $\mathrm{Ka}$ Iupiter in Leone sic $N$.

${ }^{r}$ regulum proximum] regulam proximam $N$.

s Hunc ... proximum] om. DdFb.

t VII.] om. DdFbKa.

u Deinde] De hinc FbN.

v militarem virum] virum militarem $D d$.

w qui crudeliter praeerit] om. DdKaV.

$x$ Nam] His $D d$.

y ferox] et ferox $F b$.

z agrestis] om. $F b$. 
futurus est ${ }^{a}$. Et hunc ${ }^{b}$ portendit ${ }^{c} \delta^{\lambda}$ in $m^{d}$ domo $h$ post $\delta$ receptuse. ${ }^{\mathrm{f}}$

VIII. ${ }^{g}$

Quo sublato illustrissima mulier ${ }^{\mathrm{h}}$ regnum $^{\mathrm{i}}$ sortietur $^{\mathrm{j}}$, quae licet iuste et pie praeerit ${ }^{\mathrm{k}}$. Tamen ${ }^{\mathrm{l}}$ insolenter se geret $\mathrm{ac}^{\mathrm{m}}$ regnum luxu et securitate ${ }^{\mathrm{n}}$ inficiet. Cuius tamen gubernatio ${ }^{\circ}$ successu temporis felicior ${ }^{p}$ quam a principio futuro ${ }^{q}$ decernitur. Hanc praesagit $q^{r}$ in domo octava, sed in sua exaltatione septima occupatura ${ }^{\mathrm{t}}$, ordine cedentes ${ }^{\mathrm{u}}$ planetas subsequens $^{\mathrm{v}}{ }^{\mathrm{wx}}{ }^{\mathrm{w}}$ Quodsi $^{\mathrm{y}}$ gubernatio regni ${ }^{\mathrm{z}}$ ad mulierem non deferetur ${ }^{\text {aa }}$ Respublica $e^{\mathrm{bb}}$ regno fiet ${ }^{\mathrm{cc}}$ vel $^{\mathrm{dd}}$ ó $\lambda$ i $\gamma \alpha \rho \chi^{\prime} \alpha^{\mathrm{ee}}$, sed brevi tempore ${ }^{\mathrm{ff}}$ duraturagg

${ }^{a}$ futurus est] est futurus $\mathrm{Ka}$.

b Et hunc] Hunc KaN.

c portendit] praetendit sic $N$.

d $\hat{o}$ in $m$ ] Mars in Aquario KaN.

e domo ... receptus] in domo Saturni receptus $K a$ exoriens $N$.

${ }^{\mathrm{f}}$ Et $\ldots$ receptus] om. DdFb.

g VIII.] om. DdFbKa.

h mulier] mulier quaedam $F b$.

i regnum] del. regnum ins. regno $N$.

j sortietur] potietur $N$.

${ }^{k}$ iuste ... praeerit] pia ac iusta erit $D d$.

1 Tamen] om. $N$.

m ac] et $D d$.

${ }^{\mathrm{n}}$ securitate] scurilitate $N$.

o tamen gubernatio] tum gubernans $D d$.

p felicior] foelicior $\mathrm{Ka}$ faelicior $N$.

q futuro] futura $D d K a$.

r O] Venus KaN.

s domo] om. $V$.

t septima occupatura] consituta Ka om. $V$.

u ordine cedentes] om. Ka ordines antecedentes $N$.

v planetas subsequens] om. Ka planetas subsequetur $N$.

w decernitur ... subsequens] om. $D d$.

${ }^{x}$ Hanc ... subsequens] om. Fb.

y Quodsi] Quod si $D d F b N$.

${ }^{z}$ regni] om. $F b$.

aa deferetur] deferretur $D d$ devolvatur $F b$.

bb e] ex $D d F b K a N$.

cc fiet] om. Fb.

dd vel] om. $D d$.

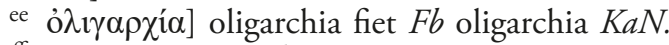

ff tempore] om. Dd.

gg duratura] om. Ka. 
IX. ${ }^{a}$

Nam postquam indigenis pertaesum ${ }^{\mathrm{b}}$ fuerit $^{\mathrm{c}}$ huius ${ }^{\mathrm{d}}$ administrationis $^{e}$. Eligent ${ }^{f}$ sibi ex regia familia regem, cui coronato parebunt. Iste erit prudens, iustus et ${ }^{\mathrm{g}}$ fortunatus planeque ${ }^{\mathrm{h}}$ similis quinto ${ }^{\mathrm{i}}$ regi, suo antecessori, sed paulo minoris ${ }^{j}$ potentiae $a^{k}$ diuturnitatis $^{1}$. Hic cognoscitur ex $\odot{ }^{\mathrm{m}}$ et $^{\mathrm{n}} \rho^{\mathrm{o}}$ in ${ }^{\mathrm{p}}$ sua exaltatione ${ }^{\mathrm{q}}$ gestantem ${ }^{\mathrm{r}} .{ }^{\text {st }}$

Ultra autem $\mathrm{me}^{\mathrm{u}}$ prognosticare $^{\mathrm{v}}$ sidera $^{\mathrm{w}}$ non permittunt. ${ }^{\mathrm{x}}$

${ }^{a}$ IX.] om. DdFbKa.

${ }^{\text {b }}$ pertaesum] pertesa $D d$ protesa $K a$ taedium $N$.

c fuerit] erit $D d F b K a$ caeperit $N$.

${ }^{d}$ huius] huiusmodi $D d F b K a N$.

e administrationis] administratio DdKa.

f eligent] eliget $F b$.

$\mathrm{g}$ et] ac $F b N$.

${ }^{\text {h }}$ planeque] om. Dd plane $N$.

i quinto] $\mathrm{V}^{\circ} N$.

j minoris] minor $F b$.

k ac] et $F b$.

${ }^{1}$ diuturnitatis] diuturnitate $K a$.

m $\odot]$ Sole $N$.

${ }^{n}$ et] om. $K a$ post $V$.

- ?] om. $K a$ Venere $N$.

p $\checkmark$ ] Ariete $K a N$.

q sua exaltatione] in sua exaltatione $K a$.

${ }^{\mathrm{r}}$ gestantem] collocato Ka om. $\mathrm{V}$.

s similis gestantem] om. Dd.

${ }^{t}$ Hic ... gestantem] om. Fb.

u autem me] autem $\mathrm{Fb}$ om. $N$.

v prognosticare] prognosticari me $F b$ prognosticari KaN.

w sidera] sydera $F b K a N$.

x Ultra ... permittunt] om. $D d$. 
Aneks 2

Skrócone Vaticinium - wersja z sześcioma wła d c a m i

Poniżej podaję tekst „skróconej” przepowiedni elekcyjnej, która w różnych postaciach jest zachowana w ośmiu znanych przekazach. Jako punkt wyjścia przyjmuję przekaz $L a$ (z jedną korektą wprowadzoną za $B$ oraz $C$ w miejscu, gdzie przekaz $L a$ został zepsuty przez kopistę). Celem niniejszego aneksu nie jest dostarczenie definitywnej postaci tekstu - ta bowiem wydaje się niemożliwa - a jedynie wskazanie w oparciu o najprawdopodobniej najstarszy przekaz tego wariantu przepowiedni kierunków modyfikacji tekstu w kolejnych odpisach. Chociaż przekaz $L b$ łącznie z przekazem $W d$ skłonny jestem uznawać za mieszane, $L b$ różni się od tego drugiego tym, iż składa się z dwu wyraźnych części, a pierwsza z nich wykazuje związek z tradycją krótkiej, sześcioelementowej przepowiedni elekcyjnej. Postanowiono włączyć zatem tę część $L b$ do niniejszego aneksu, aby pokazać również swoistą ciągłość pomiędzy poszczególnymi nurtami tradycji Retykowego Vaticinium.

Chociaż wszystkie podane niżej przekazy opierają się na enumeracji sześciu władców, zespół ten odznacza się niejednorodną strukturą i składa się $\mathrm{w}$ istocie $\mathrm{z}$ dwu, a nawet trzech podgrup. Za cechę dystynktywną uznano tutaj kolejność, w jakiej wymieniany jest władca określany jako „wielki książę” („magnus princeps” - w grupie $B D c L a L b$ został on wymieniony jako drugi, w CLcM jako trzeci) oraz władca pochodzący z „małej rodziny” („ex parvae familiae” - w grupie $B D c L a L b$ jest trzeci, w $C L c M$ - drugi). Ta różnica pozwala przypuszczać, że poszczególne grupy, choć wyrastające z jednego pnia, tworzą oddzielne odgałęzienia tej samej tradycji, jednak pomiędzy żadnym z tworzących je przekazów nie udało się wykazać bezpośrednich zależności. Połączenie tych dwóch świadków, z preferencją dla grupy $B L a L b D c$ jako punktu odniesienia w kwestii kolejności władców, służy tutaj dostarczeniu poglądowego materiału mającego zilustrować modyfikacje tekstu, który pod wieloma innymi względami jest jednorodny.

Osobną podgrupę stanowią pochodzące z Gdańska siedemnastowieczne przekazy $D a$ oraz $D b$, które w kwestii kolejności władców podążają za grupą $C L c M$, jednak zarówno od przekazów z tej grupy, jak i przekazów z $B D c L a L b$ różnią się tym, że charakterystyki władców są w nich zdecydowanie bardziej rozbudowane. To zadecydowało 
o łącznym potraktowaniu dwóch pierwszych grup oraz wyodrębnieniu grupy $D a D b$, która formułą zaczyna się zbliżać do przekazów typu mieszanego. Należy przy tym zaznaczyć, że tekst w $D a$ i $D b$ jest identyczny, jednak z uwagi na pewne nieścisłości pojawiające się w tytule $D a$, a stanowiące kolejny przykład postępującego zniekształcenia nazwiska Retyka, to drugi z tych przekazów uznano za bardziej wiarygodny.

Źródła:

$B \quad$ Berlin, Staatsbibliothek, Ms. germ. fol. 143, k. 437rec.

C Città del Vaticano, Bibliotheca Apostolica Vaticana, Ottob. lat. 2642, k. 94

Da Gdańsk, Biblioteka Gdańska PAN, Ms. 694, k. 201rec.-202ver.

Db Gdańsk, Biblioteka Gdańska PAN, Ms. 724, k. 109ver.

Dc Gdańsk, Biblioteka Gdańska PAN, Ms. 821, k. 2rec.

La Kraków, Biblioteka XX. Czartoryskich, rkps 1292, s. 8

Lb Kraków, Biblioteka XX. Czartoryskich, rkps 1657 IV, s. 596

Lc Kraków, Biblioteka XX. Czartoryskich, rkps 1947, s. 50

$M$ Lwów, Biblioteka Naukowa im. W. Stefanyka (olim Lwów, Biblioteka Zakładu Narodowego im. Ossolińskich), fond 5, rkps 189 , s. 8

Oznaczenia i skróty:

$<>$ koniektura

del. delevit (tekst wykreślony)

ins. inseruit (tekst wprowadzony później)

om. omisit (tekst pominięty)

add. addidit (tekst dodany w danym przekazie)

sic tak w rękopisie 


\section{Wariant podstawowy $(B D c L a L b-C L c M)$}

Vaticinium $^{\mathrm{a}}$ Rethici $^{\mathrm{b}}$ doctoris medici $^{\mathrm{c}}$ et $^{\mathrm{d}}$ astronomiae $^{\mathrm{e}}$ de electione ${ }^{\mathrm{f}}$ regum Poloniae ${ }^{g}$ statim factum ${ }^{\mathrm{h}}$ post $^{\mathrm{i}}$ obitum ${ }^{\mathrm{j}}$ regis Sigismundi Augusti $^{\mathrm{k}}$ anno Domini $1571^{1}$

Primus $^{\mathrm{m}}$ erit Gallus ${ }^{\mathrm{n}}$ qui $^{\mathrm{o}}$ magno cum ${ }^{\mathrm{P}}$ periculo regnum imperabit $^{\mathrm{q}}$, paulo ${ }^{\mathrm{r}}$ post coronatione $\mathrm{s}^{\mathrm{s}}$ erit profugus ${ }^{\mathrm{t}}$.

Secundus ${ }^{\mathrm{u}}$ erit magnus princeps ${ }^{\mathrm{v}}$ qui $^{\mathrm{w}}$ sine corona regnabit $^{\mathrm{x}}$.

a Vaticinium] Iudicium $B$ Judicium $L b M$ Prognostic $L c$.

b Rethici] Rhetici $B$ Georgii Rhetici $C$ D. Rhetici $D c$ Domini Georgii Rethen sic $L b$ Retici $L c$.

c doctoris medici] doctoris medicinae $B M$ medicinae doctoris $C$ doctoris medici $D c$ om. $L b$ doctoris $L c$.

d et] om. $L b$.

e astronomiae] astronomi peritissimi $B D c$ astronomi $C$ astronomiae peritissimi $L b M$ astrologi $L c$.

f electione] regnatione $L c$ electione et gubernatione $D c$.

g regum Poloniae] Polonorum regum $L b$ regum Polonorum $M$.

h statim factum] factum $B D c$ scriptum $C$ om. $L b$ AD 1501 sic $L c$ facta $M$.

i post] ante $D c$ om. $L b$.

j obitum] decessum $L c$.

${ }^{k}$ regis Sigismundi Augusti] Sigismundi Augusti regis $C$ Domini Sigismundi Augusti Dc om. LbM.

${ }^{1}$ anno Domini 1571] anno M.D.LXXI $C$ anno $1571 D c$ anno 1571 editum $L b$ $1551 \mathrm{Mom}$. Lc.

m Primus] I. $B$ Primus rex DcM1. Lb.

${ }^{n}$ Gallus] peregrinus ex Regione longe absita $D c$.

${ }^{\circ}$ qui] om. CLbM.

p cum] om. BCLbLc.

q regnum imperabit] regnum intrabit $B C M$ intrabit regnum $D c L b$.

${ }^{\mathrm{r}}$ paulo] sed paulo $C$ et paulo $D c$ paululo $L b$ pauli $M$.

s coronatione] coronationem $B D c M$ coronationem suam $C$ om. LbLcRb.

${ }^{\mathrm{t}}$ erit profugus] fugiet $C$ praefecturus $L b \mid a d d$. Henricus Rex Galliae $D c$ post aliquot annos occidetur ob varias in fide dissensiones $L c$ (Henricus) $M$.

u Secundus] II. $B$ Secundus rex $D c$ 2. Lb Tertius $L c M C$.

$\checkmark$ magnus princeps] magnus princeps et pater patriae $L b$ rex electus et adversus regno privabitur et erit captus spoliatusque dimissus ad suos $L c$.

w qui] sed $B L b L c C$ et $D c M$.

${ }^{x}$ sine ... regnabit] sine coronatione manebit $D c$ non diu durabit sine corona $L b$ sine corona rediit $L c \mid$ add. Maximilianus Romanorum Imperator $D c$ Maximilianus Archidux Austriae $M$. 
Tertius $^{\mathrm{a}}$ erit homo pauper ${ }^{\mathrm{b}}$ ex parvae familiae ${ }^{\mathrm{c}}$ cuius regni ${ }^{\mathrm{d}}$ gubernatio ${ }^{\mathrm{e}}$ erit tristis $\mathrm{f}^{\mathrm{f}} \mathrm{Is}^{\mathrm{g}}$ adiunget ${ }^{\mathrm{h}}$ sibi $^{\mathrm{i}}$ in administratione homini sibi similem et in tyrannum parvaeque familiae equestris ordinis ${ }^{j}$.

Quartus $^{\mathrm{k}}$ erit ex numero ${ }^{\mathrm{l}}$ Poloniae $^{\mathrm{m}}$ homo pius et foelix ${ }^{\mathrm{n}}$, sed gubernatio eius ${ }^{\mathrm{o}}$ non late se extendet. ${ }^{\mathrm{P}}$

Quintus $^{\mathrm{q}}$ erit peregrinus homo ${ }^{\mathrm{r}}$ foelicissimus ${ }^{\mathrm{s}}$, hostes ${ }^{\mathrm{t}}$ profligabit $^{\mathrm{u}}$, $<$ tranquillam gubernationem $>^{\mathrm{v}}$ id obtinebit ${ }^{\mathrm{w}}$, nec is diu durabit ${ }^{\mathrm{x}}$.

a Tertius] III. B Tertius rex $D c$ 3. $L b$ Secundus LcMC.b

b homo pauper] rex Poloniae $L c$.

c ex parvae familiae] parvaeque familiae $B C D c L b$ parvae familiae $L c$.

d regni] om. CM.

e gubernatio] gubernatione $L c$.

f erit tristis] iustissima $L b$ multi perturbabuntur $L c$.

g Is] et $C o m$. DcLc in $M$.

h adiunget] om. $L c$ adsiscet $D c$.

i sibi] om. Lc.

$j$ in ... ordinis] hominem tyrannicum, cuius gubernatio non durabit $B$ hominem tyrannum. Eius gubernatio non durabit $C$ hominem tyrannum sed ejus gubernatio non diu manebit $D c$ hominem Tyrannum, eius gubernatio non diu durabit $L b$ om. Lc hominem Tiranum cuius gubernatio non diu durabit $M \mid$ add. Stephanus Bathorius $D c$ Stephanus Bathori $M$.

k Quartus] IV. B Quartus rex $D c$ 4. $L b$.

${ }^{1}$ ex numero] indigena $L c$ ex num pro $M$.

m Poloniae] Polonorum BCDcLbM om. Lc.

${ }^{\mathrm{n}}$ pius et foelix] pius et felix $B M$ foelix ac pius $L b$ duabus coronis coronabitur cum magno ipsius vitae periculo coniuge una orbabitur prole pulchra gaudens secunda vero relicta cum dissensio Repub. Vita ipsius alienabitur cuius gubernatio vitae extendit regnabit annos 49 menses aliquot $L c$.

o sed gubernatio eius] sed eius gubernatio $D c$ sed gubernatio ipsius $L b$ om. Lc.

p late se extendet] om. $L c$ late se extenitet $M \mid$ add. Sigismundus $D c$ Sigismundus 3. $M$.

q Quintus] V. B Quintus rex $D c 5 . L b$.

${ }^{r}$ peregrinus homo] homo $L c$ homo peregrinus $M$.

${ }^{s}$ foelicissimus] felicissimus $B C D c L b$ fortissimus $M$.

${ }^{\mathrm{t}}$ hostes] is hostes $L b$ felicissimus bellicosissimus $L c$ hostis $M$.

u profligabit] profligabit armata manu et $L b$ profugabit $M$.

$\checkmark$ tranquillam gubernationem] tranquilitatem, gubernatio $L a$ tranquillitatem sanctam gerens Rempub. pacatam $L c$ tranquilitatem Reipublicae $M$.

w id obtinebit] obtinebit $B C D c L b$ om. $L c$ reddet $M$.

${ }^{x}$ nec is diu durabit] sed non diu foelix $B$ felix $C$ sed non diu erit $D c$ sed non diu durabit $L c$ his diu durabit $M \mid$ add. Vladislaus quartus, Sigismundi Filius $D c$ Vladislaus 4. $M$. 
Sextus $^{\mathrm{a}}$ erit $^{\mathrm{b}}$ insignis $^{\mathrm{c}}$ familiae ${ }^{\mathrm{d}}$ fortunatissimus ${ }^{\mathrm{e}}$ et $^{\mathrm{f}}$ ultimus $^{\mathrm{g}}$, cuius ${ }^{\mathrm{h}}$ imperium $^{\mathrm{i}}$ erit $^{\mathrm{j}}$ foelicissimum et tranquilum ${ }^{\mathrm{k}}$.

Omnes ${ }^{1}$ sine haerede ${ }^{\mathrm{m}}$ manebunt $^{\mathrm{n}}$.

a Sextus] VI. B 6. $L b$ Sextus et ultimus $L c$.

b erit] om. $B L c$.

c insignis] homo insignis $B C D c L b$ insignus $M$.

d familiae] om. $L c$.

e fortunatissimus] princeps fortunatissimus $C$ fortassis $D c L b$ peregrinus $L c$ fortis $M$.

f et] om. LbLc.

g ultimus] ultimus Rex Poloniae Dc om. $L c$.

h cuius] om. $B$ eius $C$.

i Imperium] imperatio regni $D c$ imperium regni $L b$ gubernatio ultima Reipub. Inimicos Ecclesiae extirpabit ad unit<atem $>$ fidei inducet Turcam cum vicem profligabit, iura et $\mathrm{p}<$ rivilegia $><\ldots>L c$.

j erit] om. Lc regni $M$.

${ }^{\mathrm{k}}$ foelicissimum et tranquilum] tranquillum $B C$ felicissimum et tranquillum $L b$ om. $L c$ felicissimum et tranquillissimum $M$.

${ }^{1}$ Omnes] Omnes hi $C$ Omnes reges Dc om. $L c$.

m sine haerede] om. Lc del. $M$.

${ }^{\mathrm{n}}$ manebunt] peribunt $B$ om. $L b L c$ regnabunt $M \mid$ add. Joannes Casimirus $M$. 
Wariant „gdański” $(D a D b)$

Vaticinium Anno 1551 Betij Retici ${ }^{\text {a }}$ Doctoris et Astrologi Doctissimi Medici De Regnatione Regni Poloniae post decessum Sigismundi Augusti

Erit Poloniae Rex Gallus, qui magno periculo intrabit. Paulo post aliquot annos occidetur, ubi variae dissensiones excitabuntur.

Postea erit Rex parvae familiae, cujus Regni Gubernatione multi perturbabuntur.

Postea erit electus et adversus Regno privabitur et erit captus spoliatusq[ue] dimissus ad suos sine corona redibit.

Postea erit indigena homo pius et foelix ${ }^{b}$, duabus coronis coronabitur; cum magno ipsius periculo. Coniuge una orbabitur, prole pulchra gaudens. Secunda retro relicta cum dissensione in Republica vita ipsius alienabitur, cuius gubernatio late se extendet, regnabit annos quadraginta sex, menses aliquot.

Postea erit homo foelicissimus ${ }^{\mathrm{c}}$, hostes profligabit, tranquillitatem sanctam gerens, Rempublicam tranquillam paratamque ${ }^{d}$ per annos quindecim non diu durabit.

a Retici] Retycii $D a$.

b foelix] felix $D a$.

c foelicissimus] felicissimus $D a$.

d paratamque] pacatamque $D a$. 
Aneks 3

Trzy warianty przepowiedni elekcyjnej w języku polskim

W poniższym aneksie podaję trzy warianty polskiego przekładu przepowiedni elekcyjnej. Najstarszym z tych przekazów jest $R a$, który znajduje się w kopiariuszu powstałym w połowie XVII w. w kręgu Jakuba Michałowskiego, natomiast przekazy $F e$ oraz $K c$ datować należy na przełom XVII i XVIII w. - przemawia za tym fakt, iż w obu rękopisach najpóźniejszym zidentyfikowanym przez kopistę w adnotacji marginalnej władcą elekcyjnym jest August II Mocny, natomiast brak wzmianek na temat Stanisława Leszczyńskiego przemawia za uznaniem obu odpisów za pochodzące z okresu pierwszego panowania Wettyna. W przeciwieństwie do rozwiązania zastosowanego w odniesieniu do wariantów łacińskich podanych w aneksach 1 i 2 zdecydowano się nie kolacjonować trzech przekazów, ponieważ rozbieżności występujące pomiędzy nimi sugerują, że mamy do czynienia z trzema niezależnymi tekstami, o czym świadczą znaczące różnice syntaktyczne i leksykalne. Wszystkie trzy przekazy, co należy podkreślić, świadczą o daleko idącym nieporozumieniu odnośnie do autorstwa przepowiedni (każdy z nich w odmienny sposób zniekształca nazwisko Retyka) oraz okoliczności powstania przepowiedni (lub tej konkretnej kopii - jak to ma miejsce w wypadku „Z manuskryptu wypisanej” kopii $K c$ ). Przygotowując przekazy te do druku, kierowano się zasadami przyjętymi dla edycji tekstów staropolskich w wersji B (por. Zasady wydawania tekstów staropolskich. Projekt, Warszawa 1955, s. 92-100), a zatem poddano modernizacji ortografię, uwspółcześniono interpunkcję i nie zachowano oryginalnego układu tekstu na stronie. $Z$ uwagi na specyfikę źródła postanowiono jednak uwzględnić takie aspekty rękopisu, których odnotowywanie zarezerwowano dla edycji krytycznych typu A, a mianowicie dopiski marginalne oraz wskazanie miejsc, w których kopista popełnił błąd.

Źródła:

Fe Kórnik, Biblioteka Kórnicka PAN, rkps 420, k. 247ver.-248 rec.

Kc Kraków, Biblioteka Jagiellońska, rkps 921, k. 1rec.-ver.

Ra Warszawa, Biblioteka Narodowa, rkps 6634 III, k. 207rec. 
Oznaczenia i skróty:

$<$ koniektura

[ ] rozwinięcie skrótu

in $m g$. in margine (na marginesie)

a.c. ante correcturam (tekst przed naniesieniem poprawki) 
Przekaz warszawski $(R a)$

Practica ${ }^{a}$ doctoris Klitricii za panowania króla Zygmu[nta] Augusta uczyniona

Wedle biegów niebieskich jaśnie się znaczy, iż króla tego panowanie nie tylko trwałe będzie, ale im dalej tym więcej sławniejsze będzie $^{\text {b }}$, które ani wojna, ani rozsterki, jeśliby co takiego przyszło, póki on żyw, być nie może.

A gdy z tego świata zejdzie łaskawe książę w sprawiedliwości i pobożności, po nim nastanie, ale bardzo krociuchny czas będzie, tak iż gdyc pocznie królować, za jakimsi przypadkiem odjedzie, a panowanie jego prędko ustanie.

Gdy już tego zacnego ks[iąż[ę]cia panowanie ustanie, opanuje królestwo niejaki starzec złośliwy, srogi, łakomy, z podłej familijej, którego panowanie smutne i żałosne ku upadku albo zginieniu królestwa tego będzie ${ }^{\mathrm{d}}$ przyłączy sobie podobnego w rządzeniu królestwa, ale sroższego i okrutniejszego niż sam.

Potym będzie wybran $\mathrm{z}$ swoich obywatelów $\mathrm{s}<\mathrm{z}>$ lacheckiego rodzaju młodzieniec, książę chytre i chciwe, w rzeczach rycerskich biegły, którye na wojnie zginie. Jego królestwo sprawowane mierne znaczy.

A gdy tego króla rządzenie ustanie, zacne książę wielkiej familijej, wspaniałej myśli więcej $<$ mocą $>^{\mathrm{f}}$, niźli przez elekcyją te królestwo opanujegs, który szczęśliwie i mężnie i długo panować będzie, granice do tego rozszerzy, czasu wojny i pokoju z wielkim pożytkiem tego królestwa będzie nad dziw, uciśnie złe a ubogaci dobre zwycięstwem, wielkim w tym królestwie będzie, nieprzyjaciołom swym uniżającym się odpuści, a przeciwiających się porazi i rozgromi śmiele, z którego familijej w tym królestwie długo królować będą i sam przez jakieś fata po długim królowaniu zejdzie.

\footnotetext{
a Practica] praktika $R a$.

b Wedle ... będzie] Augusta to znaczyło add. mg. Ra.

c A gdy ... iż gdy] Francuza to znaczyło add. mg. Ra.

d Ddy ... będzie] Batore[g]o to znaczyło a przyłąc $<$ z $>$ enie kanclerz<a $>a d d$. $m g$. $R a$.

e Potym ... który] Maximilia[na] to znaczyło add. mg. Ra.

${ }^{f}$ mocal motą Ra.

g A gdy ... opanuje] Zygmunta III to znaczyło add. mg. Ra.
} 
Po tym nastąpi spokojne książę, jednak mocą, imieniem królować będzie, któremu rychle ${ }^{\mathrm{h}}$ śmierć królestwo odejmie.

Po tym niektóry mąż rycerski królestwa dostąpi, który okrutnie będzie panował, człek srogi, okrutny i gruby nie otyły ma być, którego gdy nie stanie, zacna ${ }^{i}$ niewiasta za szczęściem opanuje, która sprawiedliwie królestwo sprawować będzie, jednak za szaleństwem się uda, a w szaleństwie bezpieczność zbytek rozmowy wszakże ku końcowi niźli z przodku panowanie jej szczęśliwsze będzie. A jeśli rządzenie królestwa niewieście będzie przyczytane, z Rzeczypospolitej jiele $<$ rządzy $>^{\mathrm{k}}$ w Królestwie będzie, a uprzykrzeniem się takiego rządu obywatelom w Królestwie krótko taki rząd trwać będzie.

Po tym obiorą sobie z domu królewskiego króla, które[g]o ukoronowania posłuszni będą. Ten będzie sprawiedliwy, mądry i szczę́liwy i prawie piątemu królowi, przodkowi swemu, podobny, wszakże coś mniejszą władzą i dostojnością.

h rychle] w rychle $R a$.

i zacna] a linea in $R a$.

j z Rzeczypospolitej] a linea in $R a$.

${ }^{k}$ rządzy] rządzyw $R a$. 
Przekaz kórnicki $(F e)$

Prognostyk astronoma krakowskiego Rescyjusza o sukcesyji królów polskich po śmierci Augusta Pierwszego króla polskiego w roku 1552.

1mo. Po śmierci Augusta króla na tron polski wstąpi Francuz, który z wielkim niebezpieczeństwem do polskiej wniejdzie, wkrótce jednak odbieży, a po lat kilku dla dyssensyi w wierze zabity będzie. ${ }^{a}$

2do. Po nim wstąi ${ }^{b}$ na królestwo człowiek małej familijej, którego gubernacyją różni będą turbować. ${ }^{c}$

3tio. Obiorą po tym adwersarze za króla ks[ię]cia jednego, który więźniem będzie, wypuszczony zaś, wszystko straciwszy, powróci do swego kraju bez korony. ${ }^{\mathrm{d}}$

4. Zostanie tedy panem indygena polski, człowiek pobożny i szczęśliwy, ten dwiema koronami będzie ukoronowany. Po śmierci pierwszej żony w wielkie niebezpieczeństwo życia wpadnie, drugą zaś pojąwszy, w potomstwo obfitować będzie, ale dla niezgód w królestwie życie jego będzie skrócone, daleko jednak rozszerzy się jego gubernium. ${ }^{\mathrm{e}}$

5. Nastąmpi po nim na królestwo szczęśliwy nader, który zwyciężywszy nieprzyjaciół, uczyni koronę spokojną i bezpieczną, ale ten niedługo panować będzie. ${ }^{f}$

6. Królować po tym będzie człowiek zacny peregrynant, wojenny, popędliwy, którego gubernacyja będzie ostatnia. Nieprzyjaciół Kościoła św. wykorzeni i wielu do uznania wiary przywiedzie, prawa, przywileje różnemi artykułami przyozdobi, Turczyna z sąsiadami ukróci, zdrady rozboje i najazdy domowe poskromi, szlachtę od opressyji poddanych uwolni i dobry rząd do pory swojej przyprowadzi. Po jego zejściu głód, mór, najazdy nieprzyjaciół i inne nieszczęścia do Polski poprzychodzą. ${ }^{\mathrm{g}}$

7. Gdy ten ustąpi ${ }^{\mathrm{h}} \mathrm{z}$ państwa, obrany będzie za króla ksiązę łaskawy, sprawiedliwością i słusznością znakomity, który bardzo krótko

\footnotetext{
a 1 mo ... będzie] Henricus Valesius add. Fe.

b wstąpi] wstąmpi $\mathrm{Fe}$.

c 2do ... turbować] Stephanus Battori add. Fe.

d 3 tio ... korony] Maximilianus add. Fe.

e 4 .... gubernium] Zygmunt Trzeci add. Fe.

f 5 . ... będzie] Władysław Czwarty add. Fe.

g $6 . .$. poprzychodza] Jan Kazimierz add. Fe.

h ustąpi] ustąmpi $F e$.
} 
panować będzie. Gdy zaś tego pana zacnego niegodnym prawem śmierć zbierze. ${ }^{i}$

8. Nastąpi ${ }^{j}$ na królestwo jeden człowiek stateczny, łakomy z podłej familijej urodzony, którego gubernacyja nieprzyjaciołom u wielu szkodliwa i ku zgubie będzie. Przybierze sobie towarzysza dożywotniego, we wszystkim sobie podobnego, bardziej jednak łakomego i nieużytego. ${ }^{\mathrm{k}}$

9no. Po tych obrany będzie cudzoziemiec, kawaler urodzony, książę młody, chytry i ambicyjant, trybu wojennego wiadomy, który jednak na wojnie albo w domu mieczem zgonie. Tego panowania lata pomierne będą. Tu wolności polskiej ciężka opresyja.

10. Gdy zaś panowanie tego ustanie książę jeden zacny z prześwietnej familijej urodzony, wspaniały i potentat, bardziej przez potencyją niżeli przez wolną elekcyją to królestwo opanuje, szczęśliwie i bardzo długo panować będzie, który jako w pokoju sprawiedliwością, tak na wojnie mocą, $\mathrm{z}$ wielkim tego królestwa pożytkiem będzie rządził ${ }^{\mathrm{m}}$. Złych przedziwnemi sposobami karać będzie, dobrych zaś nagradzać, zwycięzca i tryjumfator, szaniec królestwa tego i chwałę swego imienia wzdłuż i wszerz daleko rozciągnie, pokornie poddającym się nieprzyjaciołom odpuści, sprzeciwiających się zaś pod swoję władzę podbije tak dalece, że ledwie kto życzyć sobie może lepszego i szczęśliwszego pana, z którego też familijej długo u nas królowie będą. Ale wszyscy jesteśmy podlegli śmiertelności i ten książę, czyli raczej dziedzic, niegodzien śmierci, po długo bardzo panowaniu umrze.

11. $\mathrm{Na}$ miejscu jego nastąpi ${ }^{\mathrm{n}}$ dobry, łaskawy i spokojny książę, ale ten obrany chociaż królewskim imieniem i władzą panować będzie, nie wiem jednak czemu za żywota swego nie będzie koronowany.

12. Dostanie się po tym władza królewska do żołnierza, który okrutnie rządzić będzie jako człowiek dziki, obłudny, tyran i nigdy niezmiękczony.

13. Tego jak się pozbędzie Polska, prześwietna pani królestwem tym władać będzie, która choć będzie rządził, jednak życie jej swawolne, zbytkiem i okrucieństwem zarazi, szczęśliwsza jednak będzie jej gubernacyja czasem, niż była na początku. Jeśliby zaś dalej panowanie

\footnotetext{
7. ... zbierze] Michał add. Fe.

j Nastąpi] Nastąmpi $\mathrm{Fe}$.

k 8. ... nieużytego] Jan III add. Fe.

1 9no ... opresyja] August Wtóry add. Fe.

$\mathrm{m}$ rządził] lectio incerta.

${ }^{n}$ nastąpi] nastąmpi $F e$.
} 
jej spadło na białą głowę pewnie Rzecząpospolitą i królestwem kilku oraz wojewodów będzie rządziło, ale to niedługo ma potrwać.

14. Bo gdy uciemięży królestwa obywatelów, rządcy obiorą sobie króla z familijej królewskiej, któremu ukoronowanemu będą posłuszni. Ten będzie rozumny, sprawiedliwy, szczęśliwy, podobny antecessorowi piątemu przed sobą, mniejszej jednak potencyji i godności. 
Przekaz krakowski $(K c)$

Wytłumaczenie z łacińskiego na polski język prognostyku przez niegdy Gecyjusza nazwanego doktora o następujących królach polskich z manuskryptu wypisane

Po śmierci Zygmunta Augusta będzie król polski Francuz, który z wielkim niebezpieczeństwem wnidzie na państwo i krótkim czasie zjedzie z państwa i w kilka lat zabity będzie dla różnej w wierze dyssensyji. ${ }^{a}$

Po tym król Polski będzie obrany człowiek niewielkiej familiji, który swoim panowaniem potrwoży wieki i zwycięży. ${ }^{b}$

Nastąpi król obrany od przeciwnej strony, który pozbędzie wkrótce państwa, pojmany, ogołoczony, opuszczony od swoich.c

Po nim będzie król postronny, człowiek pobożny i szczęśliwy, dwiema koronowany koronami, będzie z wielkim żywota jego niebiezpieczeństwem, małżonki pozbędzie potomstwem jednak ubłogosławiony, za którego panowania długo i szeroko rozprzestrzenione będzie państwo. ${ }^{\mathrm{d}}$

Będzie król Polski najszczęśliwszy, nad nieprzyjacielem zwycięstwo otrzymać będzie, jego królestwo w zgodzie i pokoju zostawać będzie, ale niedługie jego panowanie. ${ }^{\mathrm{e}}$

Nastąpi król Polski człowiek znaczny, którego panowanie będzie ostatnie, nieprzyjaciół Kościoła Bożego, Wiary Ś[więtej] wykorzeni i do prawej wiary nawróci, przywileje i statuta koronne w różnych artykułach przyozdobi, zdrady, mężobójstwa, najazdy domowe uśmierzy, poddanych od opresyji uwolni i inne do stanu swego przywiedzie, jednak z tej rady zażwać będzie ku swojej zgubie, najazdy nieprzyjaciół do Korony nastąpią i wszytko złe na Polskę się obali. Po jego śmierci nastąpi głód, mor, rozterki i wszytko nieszczęście. ${ }^{f}$

Nastąpi łaskawy książę sprawiedliwością i pobożnością znaczny, ale w krótkim barzo czasie, gdy pocznie panować i swoję dobroć i roztropność pokazować, albo otruty będzie, albo $\mathrm{z}$ innej racyji $\mathrm{z}$ tego świata zejdzie. ${ }^{g}$

a Po ... dyssensyji] Henryk add. Kc.

b Po ... zwycięży] Stephan Batory add. Kc.

c Nastąpi ... swoich] Maximilian add. Kc.

d Po ... państwo] Zygmunt add. $K c$.

e Będzie ... panowanie] Władysław add. Kc.

f Nastąpi ... nieszczęście] Jan Kazimierz add. Kc.

g Nastąpi ... zejdzie] Michał add. Kc. 
Gdy tak znacznego i dobrotliwego pana Polska pozbędzie $<$ się ${ }^{\text {h }}$, nastąpi niektóry stary, stateczny i poważny, ale łakomy, z podłej familiji zrodzony, którego panowanie smutne, opłakane i troskliwe będzie, przysposobi sobie $\mathrm{w}$ korespondencyją towarzysza takiegoż, ale się to Rz[eczy]p[ospo]l[i]tej na nic nie przyda. ${ }^{i}$

Po tym będzie z postronnych ludzi żołnierz nowy i książę, gorączka i pyszny, trybu wojennego wiadomy, który albo na wojnie albo $\mathrm{w}$ domu zginie, którego panowanie mizerne będzie. Tu wolności polskiej opresyja będzie. ${ }^{j}$

A gdy tego króla Polska pozbędzie <się>, nastąpi na jego miejsce znaczny książę, najaśniejszej familii, potentat wielki, który barziej przez moc i potencyją swoją, niżeli przez wolną elekcyją to królestwo osiądzie, szczęśliwie i długo panować będzie, w pokoju i sprawiedliwości koronę postawi, zwycięstwy wielkiemi wsławiony, z wielki Królestwa tego pożytkiem panować będzie i rządzić, złych bez respektu karać, dobrym znacznie nagradzać będzie, zwycięzcą chwalebnym zostanie, chwałę imienia swego szyroko i długo i granicę królestwa rozpostrzeni. Poddającym się nieprzyjaciołom przepuści, sprzeciwiającym się i odpór dającym do ostatniej zguby przywiedzie, z którego familiji długo królowie u nas będą. A gdy każdy śmiertelności podlega, lubo długo panować będzie, otruty jednak zostanie.

$\mathrm{Na}$ jego miejsce nastąpi dobry, łaskawy i spokojny książę, który lubo obrany jako król, władzą królewską rozkazować będzie, ale nie wiem, z jakiej racyji koronowany nie będzie.

Po nim do żołnierza królestwo należeć będzie, długo i okrutnie sprawować je będzie, człowiek tetryk, złośliwy, groźny i przewrotny.

Po jego śmierci najaśniejsza pani osiądzie to królestwo, które według słuszności należeć jej będzie, ale niecnotliwie sprawować się będzie i królestwo niebezpieczeństwa i płaczu nabawi, za której panowania w następujących po tym czasach szczęśliwsze będzie niżeli początki. A gdy ta białogłowa panować będzie Rz[ecz]p[ospo]l[i] ta i Królestwo u postronnych narodów u wszytkich w pośmiewisku będzie. A wkrótce przybierze sobie męża i króla z królewskiej familijej, któremu koronowanemu posłuszni będą. Ten będzie mądry, sprawiedliwy, szczęśliwy, podobny piątemu królowi, antecessorowi swemu, ale mniejszy potencyją i godnością.

Więcej mi prognostykować znaki nie dopuszczają.

\footnotetext{
h się] om. $K c$.

${ }^{\mathrm{i}}$ Gdy ... nie przyda] Jan Trzeci add. $K c$.

j Po .. będzie] August Wtóry add. Kc.
} 
Aneks 4

Wersja niemiecka przepowiedni elekcyjnej

Poniżej podaję tekst przepowiedni elekcyjnej Retyka w wersji niemieckiej, zachowanej obecnie w postaci dwóch przekazów znajdujących się w Bibliotece Gdańskiej PAN (De oraz $D f f)$. Kierując się przekazem $D e$, uwzględniłem również drobne różnice pomiędzy tym przekazem oraz $D f$, wskazując je w aparacie tekstowym. Tam również podane zostały noty marginalne towarzyszące obu przekazom.

Źródła:

De Gdańsk, Biblioteka Gdańska PAN, Ms. 907, s. 68

Df Gdańsk, Biblioteka Gdańska PAN, Ms. 1293, k. 157ver.-158 ver.

Skróty:

om. omisit (tekst pominięty)

in $m g$. in margine (nota marginalna)

Vaticinium, oder ${ }^{\mathrm{a}}$ Weissagung Doctoris Retzij ${ }^{\mathrm{b}}$, des sehr erfahrnen Medici et Astronomi, von der Wahl unnd Regierung der Könige ${ }^{\mathrm{c}} \mathrm{zu}$ Pohlen, Geschehen fürm ${ }^{\mathrm{d}}$ Tode $^{\mathrm{e}}$ Königes $^{\mathrm{f}}$ Sigismundi Augusti Anno 1571

gDer Erste, wird ein frembling sein auss einer fernen abgelegenen Landtschafft, welcher mit grosser grefahr wieder ins Reich kommen, unnd baldt nach der Krönung verflüchtig werden.

${ }^{h}$ Der Ander, wirdt ein grosser Fürst sein, aber ohne Krönung bleiben.

${ }^{i}$ Der Dritte, Wird ein armeer Herr sein, eines geringen Geschechtes unnd Herkommens, welches Regierung wird traurig sein, er wird

a Vaticinium, oder] om. Df.

b Retzij] Joannis Rezij $D f$.

c Könige] Koninge $D f$.

d fürm] kurtz vorm $D f$

e Tode] Totte $D f$.

${ }^{\text {f }}$ Königes] Koning $D f$.

$\mathrm{g}$ in mg. Henricus von Valois, zog nach Franckreich De Henricus 4 ex Gallia $D f$.

$\mathrm{h}$ in $m g$. Maximilianus Caesar Ward neben Bathori orwehlet De Caesar Maximilian $2 D f$.

i in mg. Stephanus Bathori, Dux Transilvaniae De Stephanus Botorius sic Df. 
sich an einen Tyrannen hengen, aber seine Regierung wird nicht lange wehren.

jDer Vierde, Wird auss der Zahl der Pohlen sein, ein Hochfürchtiger Glückseliger Herr, aber seine Regierung word sich nicht weit ausstrecken.

${ }^{k}$ Der Fünffte, Wird ein sehr glückhafftiger Herr sein, er wird die Feinde schlagen, unnd eine grausame Regierung erlangen, wird aber nicht lange regieren.

${ }^{1}$ Der Sechste, Wird eines trefflichen Geschlechtes unnd Herkommens sein, unnd vielleicht der Lezte König in Pohlen, welches Regierung wirdt sehr glücklich unnd rühmlich sein.

j in $m g$. Sigismundus Tertius, Erbe den Kron Schweden De Sigismundus 3 Suecus $D f$.

k in mg. Wladisslaus Quartus De.

${ }^{1}$ in mg. Johannes Casimirus Hodiernus Rex De. 


\section{Bibliografia}

G. Almási, The Uses of Humanism: Johannes Sambucus (1531-1584), Andreas Dudith (1533-1589), and the Republic of Letters in East Central Europe, Leiden-Boston 2009

M. Azzolini, Refining the Astrologer's Art. Astrological Diagrams in Bodleian MS Canon. Misc. 24 and Cardanos "Libelli Quinque” (1547), „Journal for the History of Astronomy", 42, 2011, 1, s. 1-25

H. Barycz, Krakowski pobyt Jerzego Joachima Retyka, w: idem, Między Krakowem a Warmia i Mazurami, Olsztyn 1987, s. 169-212

L. A. Birkenmajer, Mikotaj Kopernik. Część I: Studya nad pracami Kopernika oraz materyaty biograficzne, Kraków 1900

K. H. Burmeister, Georg Joachim Rhetikus 1514-1574. Eine Bio-Bibliographie, Bd. 1-3, Wiesbaden 1968

M. Choptiany, „Dyjalog” Kasjana Sakowicza (1642) jako druk i rękopis. Siedemnastowieczne spory kalendarzowe i problem obiegu idei $w$ kulturze staropolskiej, „Pamiętnik Literacki”, 107, 2017, w druku

M. Choptiany, „Przestroga” Jana Latosza z 1595 roku. Prolegomena do edycji krytycznej na podstawie siedemnastowiecznego rękopisu z Biblioteki Narodowej $w$ Warszawie, „Terminus”, 16, 2014, nr 2, s. 175-192

M. Choptiany, „Ultra prognosticare me sidera non permittunt”. O astrologicznych źródtach przepowiedni elekcyjnej Jerzego Joachima Retyka, „Kwartalnik Historii Nauki i Techniki”, 61, 2016, nr 4, w druku

D. Danielson, The First Copernican. Georg Joachim Rheticus and the Rise of the Copernican Revolution, New York 2006

H. Degering, Kurzes Verzeichnis der germanischen Handschriften der Preussischen Staatsbibliothek, Bd. 1: Die Handschriften in Folioformat, Leipzig 1925

J. Dianni, Pobyt J. J. Retyka w Krakowie, „Studia i Materiały z Dziejów Nauki Polskiej", 1, 1953, s. 64-80

Dudith András könyvtára. Részleges rekonstrukció, összeállította és az előszót írta J. Jankovics, I. Monok, Szeged 1993

A. Grafton, Cardano's Cosmos. The Worlds and Works of a Renaissance Astrologer, Cambridge (Mass.)-London 2001

O. Günther, Katalog der Danziger Stadtbibliothek, Bd. 1, Theil 1: Die Danzig betreffenden Handschriften, Danzig 1892

O. Günther, Katalog der Danziger Stadtbibliothek, Bd. 1, Theil 2, Danzig 1903

D. Haberland, Thomas Rehdiger - Humanist, Sammler und Begründer der Breslauer Stadtbibliothek, w: Ślaska Republika Uczonych / Schlesische Gelehrtenrepublik / Slezská védecká obec, t. 4, red. M. Hałub, A. Mańko-Matysiak, Wrocław 2010, s. 73-112

L. Hajdukiewicz, Retyk Jerzy Joachim, PSB, 21, 1988, s. 255-259 
L. Harc, Samuel Beniamin Klose (1730-1798). Studium historiograficzno-źródtoznawcze, Wrocław 2002 (Acta Universitatis Wratislaviensi; 2389 - Historia, 157)

Inwentarz rękopisów Biblioteki Zakładu Narodowego im. Ossolinskich we Wroctawiu, t. 1: Rękopisy 1505-7325, red. J. Turska, Wrocław 1948

Jakuba Michatowskiego, wojskiego lubelskiego, a później kasztelana bieckiego księga pamiętnicza, wyd. A. Z. Helcel, Kraków 1864

Katalog rękopisów Biblioteki Czartoryskich w Krakowie. Sygnatury 1682-2000, oprac. M. Kukiel, uzup. A. Homecki, Kraków 1988

Katalog rękopisów Biblioteki Narodowej, t. 7: Rękopisy 6601-7000. Zbiory Morstinów, Radziwittów, Potockich i inne rękopisy XVI-XVIII w., red. K. Muszyńska, Warszawa 1969

A. Kersten, Geneza „Nowej Gigantomachii”, „Annales Universitatis Mariae Curie-Skłodowska", Sectio F, 10, 1955, nr 1, s. 1-20

A. Kersten, Pierwszy opis obrony Jasnej Góry w roku 1655. Studia nad „Nowa Gigantomachiq" ks. Augustyna Kordeckiego, Warszawa 1958

W. Kętrzyński, Katalog rękopisów Biblioteki Zaktadu Narodowego im. Ossolińskich, t. 1, Lwów 1881

A. T. Klubiński, Diversi color - kariera przepowiedni elekcyjnej (1697-1764), „Barok”, 5, 1998, z. 1, s. 225-233

J. Kraai, Rheticus' Heliocentric Providence. A Study Concerning the Astrology and Astronomy of the Sixteenth Century, rozprawa doktorska, Universität Heidelberg, 2001, http://www.ub.uni-heidelberg.de/archiv/3254 (12 V 2016)

J. Kroczak, "Jeśli mię wieźdźba prawdziwa uwodzi...” Prognostyki i znaki cudowne w polskiej literaturze barokowej, Wrocław 2006

S. Kutrzeba, Catalogus codicum manu scriptorum Musei Principum Czartoryski Cracoviensis, vol. 2, Cracoviae 1913

I. Lewandowski, Jerzy Joachim Retyk i jego „Pochwata Prus”, „Rocznik Gdański”, 32, 1972, z. 2, s. 73-94

Z. Libiszowska, Antyszwedzka literatura propagandowa z czasów "potopu”, w: Polska w okresie drugiej wojny pótnocnej 1655-1660, t. 2: Rozprawy, Warszawa 1957, s. 481-527

B. Nadolski, Ze studiów nad życiem literackim i kultura umystowa na Pomorzu w XVI i XVII wieku, Wrocław-Warszawa-Kraków 1969

Nicolaus Copernicus Gesamtausgabe, Bd. VIII/1: Receptio Copernicana: Texte zur Aufnahme der Copernicanischen Theorie, hrsg. von H. Nobis, A. M. Pastori, Berlin 2002

J. D. North, Horoscopes and History, London 1986

Z. Nowak, Antyreformacyjna elegia Dantyszka o zagtadzie Gdańska, OiRwP, 16, 1971, s. 3-35

J. Nowak-Dłużewski, Bibliografia staropolskiej okolicznościowej poezji politycznej (XVI-XVIII), Warszawa 1964 
A. Oszczęda, $Z$ kroniki do sylwy. Wokót problemów rękopisu i druku w początkach XVII wieku. Część 1: Pieśń o zdobyciu Smoleńska Marcina Paszkowskiego. Uwagi o autorstwie i migracji tekstu, „Pamiętnik Literacki”, 102, 2011, z. 4, s. 175-180

A. Oszczęda, $Z$ kroniki do sylwy. Wokót problemów rękopisu i druku w początkach XVII wieku. Część 2: Wiersz Macieja Stryjkowskiego w lwowskim rękopisie Ossolineum, „Pamiętnik Literacki”, 104, 2013, z. 3, s. 231-248

J. Partyka, Rękopisy dworu szlacheckiego doby staropolskiej, Warszawa 1995

A. Przyboś, Michatowski Jakub, PSB, 20, 1975, s. 652-654

T. Przypkowski, Astronomia $i$ astrologia $w$ Krakowie $w$ drugiej potowie XVI wieku, w: Historia astronomii w Polsce, t. 1, red. E. Rybka, Wrocław 1975, s. $185-202$

A. Skolimowska, Vaticinium ruiturae Poloniae. Was Dantiscus Foretelling the Downfall of Poland, w: Corpus Epistularum Ioannis Dantisci, p. 5: Respublica Litteraria in Action, vol. 3: New Sources, red. K. Tomaszuk, Warsaw 2016, s. 99-113

Staropolska kultura rękopisu, red. H. Dziechcińska, Warszawa 1990

Staropolskie przepowiednie i mirabilia, oprac. J. Kroczak, Wrocław 2007

E. Śnieżyńska-Stolot, „Zamek piękny na wzgórzu...”. Horoskopy-zapomniane źródto historyczne, Kraków 2015

R. S. Westman, The Copernican Question. Prognostication, Skepticism, and Celestial Order, Berkeley-Los Angeles-London 2011.

M. Wichowa, Elementy biblioterapii w literaturze polskiej epok dawnych. Rekonesans historycznoliteracki, „Acta Universitatis Lodziensis. Folia Librorum”, 17, 2013, s. 49-66

W. Wisłocki, Katalog rękopisów Biblijoteki Uniwersytetu Jagiellońskiego, cz. 1: Wstęp. Rękopisy 1-1875, Kraków 1877

J. Włodarczyk, Wstęp, w: J. J. Retyk, Relacja pierwsza z ksiag „O obrotach” Mikotaja Kopernika, tł. I. Lewandowski, wstęp i koment. J. Włodarczyk, Warszawa 2015

\section{Manuscript Tradition of Georg Joachim Rheticus's Election Prophecy. Analysis of Accounts and Their Editions}

The paper aims to organise the issues concerning the great variety of manuscripts jointly described as the "election prophecy," supposedly made by Georg Joachim Rheticus (1514-1574), an astronomer, astrologer, and the student of Nicolaus Copernicus. The study contains a proposal of a model showing how the original Latin text of the "prophecy," the autograph of which has not been preserved to this day and which had the form of a horoscope diagram with commentary by Rheticus, underwent contamination and 
interpolation, while at the same time serving as the basis for the creation of two vernacular traditions of the text - Polish and German. The analysis of the preserved copies consists of the description of the most reliable witness of the "prophecy" tradition - the copy made in the $18^{\text {th }}$ century by Wrocław-based Enlightenment historian Samuel Beniamin Klose on the basis of the available documents of Andrzej Dudycz, which introduced the text into wider circulation - and of the discussion of other accounts which can be found in European libraries. The transformations undergone by the text of the prophecy between late $16^{\text {th }}$ century and early $18^{\text {th }}$ century are depicted in source materials annexed to the paper, containing the editions of several Latin and Polish versions of the text, as well as its German version.

Dr Michał Choptiany, adiunkt na Wydziale „Artes Liberales” Uniwersytetu Warszawskiego. Prowadzi badania nad teorią i historią retoryki, historią intelektualną epoki wczesnonowożytnej, historią nauki, historią książki i czytelnictwa. E-mail: michal.choptiany@al.uw.edu.pl. 